Board of Governors of the Federal Reserve System

International Finance Discussion Papers

Number 741

December 2002

THE ROAD TO ADOPTING THE EURO:

MONETARY POLICY AND EXCHANGE RATE REGIMES IN EU CANDIDATE COUNTRIES

Fabio M. Natalucci and Federico Ravenna

NOTE: International Finance Discussion Papers are preliminary materials circulated to stimulate discussion and critical comment. References in publications to International Finance Discussion Papers (other than an acknowledgment that the writer has had access to unpublished material) should be cleared with the author or authors. Recent IFDPs are available on the Web at www.federalreserve.gov/pubs/ifdp/. 


\title{
THE ROAD TO ADOPTING THE EURO: MONETARY POLICY AND EXCHANGE RATE REGIMES IN EU CANDIDATE COUNTRIES
}

Fabio M. Natalucci and Federico Ravenna*

\begin{abstract}
This paper examines the choice of exchange rate regime in EU candidate countries during the process of accession to the European Monetary Union (EMU). In the presence of real exchange rate appreciation due to the Balassa-Samuelson effect, candidate countries face a trade-off between trend appreciation of the nominal exchange rate and high inflation rates. In a general equilibrium model of an emerging market economy, we show that under a fixed or heavily managed exchange rate the BalassaSamuelson effect might prevent compliance with the Maastricht inflation criterion, unless a contractionary policy is adopted. We then discuss how the real exchange rate appreciation shifts the output gap/inflation variance trade-off, increasing the cost of managing or fixing the exchange rate. As a consequence, the requirement of membership in the Exchange Rate Mechanism (ERM-II) and the Maastricht inflation criterion constrain the policy choice while providing no additional benefit to countries credibly committed to joining the Euro. Finally, we show that relaxing either the exchange rate requirement or the inflation criterion has sharply different business cycle implications for the accession countries.
\end{abstract}

Keywords: Balassa-Samuelson Effect, European Union Enlargement, European Monetary Union, Exchange Rate Regimes, Taylor Rule, Monetary Policy, Transition Economies.

JEL Classifications: E52, E31, F02, F41.

* Board of Governors of the Federal Reserve System (Fabio.M.Natalucci@ frb.gov) and University of California-Santa Cruz (fravenna@ cats.ucsc.edu). We would like to thank Shaghil Ahmed, Luca Guerrieri, Dale Henderson, John Rogers, and Nathan Sheets for helpful comments, and Solange Gouvea for excellent research assistance. We also thank seminar participants at the University of California -Santa Cruz, George Washington University, the Fall 2002 Meeting of the System Committee on International Economic Analysis, the IF Workshop of the Federal Reserve Board, and the 2002 Meeting of the Society for Economic Dynamics. The views in this paper are solely the responsibility of the authors and should not be interpreted as reflecting the views of the Board of Governors of the Federal Reserve System or of any other person associated with the Federal Reserve System. Federico Ravenna acknowledges financial support from the UCSC. 


\title{
The Road to Adopting the Euro: Monetary Policy and Exchange Rate Regimes in EU Candidate Countries*
}

\author{
Fabio M. Natalucci ${ }^{\dagger} \quad$ Federico Ravenna $a^{\ddagger}$
}

December 8, 2002

\begin{abstract}
This paper examines the choice of exchange rate regime in EU candidate countries during the process of accession to the European Monetary Union (EMU). In the presence of real exchange rate appreciation due to the Balassa-Samuelson effect, candidate countries face a trade-off between trend appreciation of the nominal exchange rate and high inflation rates. In a general equilibrium model of an emerging market economy, we show that under a fixed or heavily managed exchange rate the Balassa-Samuelson effect might prevent compliance with the Maastricht inflation criterion, unless a contractionary policy is adopted. We then discuss how the real exchange rate appreciation shifts the output gap/inflation variance trade-off, increasing the cost of managing or fixing the exchange rate. As a consequence, the requirement of membership in the Exchange Rate Mechanism (ERM-II) and the Maastricht inflation criterion constrain the policy choice while providing no additional benefit to countries credibly committed to joining the Euro. Finally, we show that relaxing either the exchange rate requirement or the inflation criterion has sharply different business cycle implications for the accession countries.
\end{abstract}

JEL Classification Numbers: E52; E31; F02; F41.

Keywords: Balassa Samuelson Effect; European Union Enlargement; European Monetary Union; Exchange

Rate Regimes; Taylor Rule; Monetary Policy; Transition Economies

\footnotetext{
*We would like to thank Shaghil Ahmed, Luca Guerrieri, Dale Henderson, John Rogers, and Nathan Sheets for helpful comments, and Solange Gouvea for excellent research assistance. We also thank seminar participants at the University of California-Santa Cruz, George Washington University, the Fall 2002 Meeting of the System Committee on International Economic Analysis, the IF Workshop of the Federal Reserve Board, the 2002 Meeting of the Society for Economic Dynamics. The views expressed in this paper are solely the responsibility of the authors and should not be interpreted as reflecting the views of the Board of Governors of the Federal Reserve System or any other person associated with the Federal Reserve System. Federico Ravenna acknowledges financial support from the UCSC.

${ }^{\dagger}$ Federal Reserve Board, Division of International Finance, MS 24, Washington, DC 20551. E-mail: Fabio.M.Natalucci@frb.gov

${ }^{\ddagger}$ Corresponding author. Department of Economics, 217 Social Sciences 1, University of California-Santa Cruz, CA 95064. Email: fravenna@cats.ucsc.edu.
} 


\section{Introduction}

The European Commission report on enlargement, released on October 9, 2002, recommended that 10 candidate countries - Cyprus, Czech Republic, Estonia, Hungary, Latvia, Lithuania, Malta, Poland, Slovakia, and Slovenia - join the European Union (EU) in 2004. The new members are required, upon entry into the EU or at a later date, to participate in the ERM-II, the exchange rate arrangement between the Euro area and EU members outside the Euro area. Joining the ERM-II, i.e. limiting for at least two years exchange rate movements within a \pm 15 percent band around a central parity, is a necessary step to join the Euro currency area. Accession countries are also expected to meet the Maastricht convergence criteria for the adoption of the Euro. According to the inflation criterion, the annual inflation rate of European Monetary Union (EMU) candidates must not exceed by more than 1.5 percent the average of the three lower inflation countries in the Euro area.

The ERM-II is compatible with a number of exchange rate regimes. According to the ECOFIN Council [20], only three regimes are considered inconsistent with ERM-II: any regime without a mutually agreed central rate to the Euro, crawling pegs, and pegs to currencies other than the Euro. This paper analyzes the consequences of large productivity gains on the choice of exchange rate regimes in EU candidate countries during the process of accession to the EMU.

EU candidate countries are expected to experience - and are already experiencing - an increase in productivity growth, large capital inflows, and a sustained appreciation of the real exchange rate. As a consequence, they may face a trade-off between complying with the inflation criterion and respecting the nominal exchange rate requirement for EMU membership. In fact, since a real appreciation can be achieved through an appreciation of the nominal exchange rate, higher inflation, or a combination of both, different exchange rate regimes will generate very different outcomes in terms of the above criteria. The inflation gap with the Euro area resulting from the real appreciation pressure could be large under a fixed or heavily-managed exchange rate, leading to a violation of one of the Maastricht convergence criteria. On the contrary, countries adopting an inflation targeting regime will more likely respect the inflation criterion, but will be at risk of facing a strong appreciation of the nominal exchange rate that might violate the requirement of exchange rate stability.

Using a model calibrated for the Czech Republic, we show that the impact of the productivity-driven appreciation of the real exchange rate (the 
so-called Balassa-Samuelson effect) is twofold. First, monetary policy and the choice of exchange rate regime alone do not necessarily allow compliance with the EMU accession requirements if the Balassa-Samuelson effect is at work. Even in the absence of any business cycle shock and with full credibility, monetary policy is unlikely to ensure that the levels of inflation and exchange rate are stabilized within the required bounds. Second, under the assumption that monetary policy is conducted according to a Taylor rule, the inflation-output gap trade-off shifts, raising the cost of managing/fixing the nominal exchange rate in terms of either the output gap or the inflation variability. This variance effect cannot be avoided and affects the choice of the exchange rate regime by making a fixed exchange rate more costly in terms of output gap and inflation volatility over the business cycle.

We then evaluate the business cycle implications of relaxing either the exchange rate requirement or the Maastricht inflation criterion. We conclude that allowing for a sustained appreciation of the nominal exchange rate would deliver a lower volatility of both the output gap and inflation.

The paper is organized as follows. Section 2 reviews recent literature on the Balassa-Samuelson effect. Section 3 describes the model. Section 4 discusses the parametrization. Section 5 examines the impact of a trend increase in the tradable sector productivity under alternative monetary policies. Section 6 discusses implications for the capital inflows. Section 7 describes the variance trade-offs conditional on a simple Taylor rule. Section 8 concludes.

\section{EU Accession and the Balassa-Samuelson Effect}

Large capital inflows and sustained real exchange rate appreciation in EU accession countries can be explained by the so-called Balassa-Samuelson effect. Most of the productivity gains along the path to convergence are expected to show up in the tradable good sector. Higher productivity translates into higher wages. Assuming perfect labor mobility across sectors, wages in the non-tradable sector have to rise to comply with wage equalization. Firms in the non-tradable sector, facing relatively lower productivity gains, are then forced to increase prices and the ratio of non-tradable to tradable prices, a measure of the real exchange rate, rises. Therefore, faster productivity gains in the tradable sector translate into real appreciation.

Several papers discuss the nominal and real convergence between EU candidate countries and the Euro currency area. Buiter and Grafe [4] offer an extensive survey. Pelkmans et al. [35] provide a very detailed analysis of 
the long-run viability of the Eastern European enlargement, including a discussion about the run-up to the EMU and a description of the institutional framework.

The Balassa-Samuelson effect is considered a substantial hurdle for compliance with the nominal convergence criteria. Empirical analysis and discussion of the theoretical background can be found in De Gregorio et al. [15], Canzoneri et al. [7], Cipriani [9], Arratibel et al. [1], Egert [21], Cihak and Holub [8], Nenovsky and Dimitrova [32], Fischer [22], and Rogers [37] [38].

The literature estimates productivity growth differential between the Euro area and EU candidate countries' tradable sectors to be between $1 \%$ and $4 \%$, with most of the estimates above $2 \%$. The trend appreciation of the real exchange rate in many of the same economies is extensively documented, ranging in the 1992-1998 period from $25 \%$ in Hungary to nearly $300 \%$ in Estonia and Latvia (De Broeck and Slok [14]). Figure 1 shows the behavior of the real effective exchange rate (REER) post-1995 for a selected group of countries. However, there is disagreement as to whether the BalassaSamuelson effect can explain these large movements of the real exchange rate (see Mihaljek [31]). Changes in the real exchange rate can be disaggregated into three components: (1) the ratio between the relative price of tradable and non-tradable goods in the domestic country relative to the Euro area; (2) changes between tradable and non-tradable goods in the consumption basket; (3) the relative price of tradable goods in a common currency. Movements in the first component represent the Balassa-Samuelson effect. Changes in the second component are likely to happen, although they are not expected to play a major role. Deviations from the law of one price represent the third component. Kovacs [25] documents that changes in the non tradable component (1) in Hungary have dominated the movements of the real exchange rate between 1991 and 1996, while deviations from the law of one price for tradables do not display a clear trend. Given the very short time horizon of the data, and the fact that most of these economies had well functioning markets only in very recent years, accurate estimates are difficult.

While the discussion in the literature focuses on the magnitude and consequences of the Balassa-Samuelson effect, the quantitative analysis of alternative monetary policies is very limited. Devereux [18] is the closest model to the one developed in this paper, although the focus of his analysis is on the role of terms of trade shocks in accession countries. Laxton and Pesenti [26] examine alternative Taylor rules in a general equilibrium (GE) model calibrated on the Czech Republic. A modeling framework similar in 
spirit can also be found in the exchange-rate based stabilization literature, e.g. Mendoza and Uribe [30] and Uribe [45].

\section{The Model}

We consider a small open economy framework along the lines of Obstfeld and Rogoff [34], Devereux [17] [18], Devereux and Lane [19], Gali and Monacelli [23] and Svensson [41]. Our goal is to develop a model that fits some important characteristics of emerging market economies. In particular, the structure of the model emphasizes the role of imported intermediate inputs, the foreign component of capital goods, and the dynamics of volatile capital inflows.

The small open economy produces a non-tradable good $(N)$ and a domestic tradable good $(H)$. The latter is also produced abroad and its price is exogenously determined in the world market. Consumers work in both production sectors. Their preferences are defined over a basket of tradable $(T)$ and non-tradable $(N)$ goods. The tradable good basket includes two goods: a foreign good $(F)$, that must be imported, and the domestic good $(H)$. Consumers own the sector-specific capital and can save by holding real money balances and domestic/foreign nominal bonds. Investment goods in the $H$ and $N$ sectors are obtained by combining tradable goods $(T)$ - produced at home $(H)$ and imported $(F)$ - and non-tradable goods $(N)$. However, shares and elasticities of substitution of the investment aggregates are different from the consumption aggregate. Given the structure of investment, an increase in capital in the $H(N)$ sector requires an increase in production in both the $H$ and $N$ sectors. The domestic tradable sector $H$ uses domestic value added - a Cobb-Douglas aggregate of labor and capital - and an imported intermediate input. To introduce a role for monetary policy, we assume that the non-tradable sector, in which output is obtained by combining labor and capital, is characterized by nominal rigidities.

Four distinguishing features make the model appropriate for Central and Eastern European emerging economies. First, the domestic tradable good is both exported and consumed by domestic households. In countries like the Czech Republic and Hungary the share of consumption in imported goods is, in fact, well below 15 percent. Second, the shares in the consumption and investment baskets are different. The model therefore can account for the fact that intermediate inputs and capital goods are the main components of imports. In the Czech Republic and Hungary, for example, intermediate goods are the largest component of imports - above 50 percent - making 
these economies very exposed to external shocks. Third, the model allows for different elasticities of substitution between $T$ and $N$ goods and between $H$ and $F$ goods. Fourth, in order to analyze the implications of the BalassaSamuelson effect for inflation and nominal exchange rate, the productivity shock is built so as to mimic productivity dynamics in EU accession countries. The fact that the shock generates expectations of a prolonged increase in the productivity growth rate has important implications for the intertemporal allocation of consumption and investment.

\subsection{Consumption, Investment, and Price Composites}

Let total consumption, $C_{t}$, be a composite index of non-tradable and tradable consumption, $C_{N, t}$ and $C_{T, t}$ respectively:

$$
C_{t}=\left[\left(\gamma_{c n}\right)^{\frac{1}{\rho_{c n}}}\left(C_{N, t}\right)^{\frac{\rho_{c n}-1}{\rho_{c n}}}+\left(1-\gamma_{c n}\right)^{\frac{1}{\rho_{c n}}}\left(C_{T, t}\right)^{\frac{\rho_{c n}-1}{\rho_{c n}}}\right]^{\frac{\rho_{c n}}{\rho_{c n}-1}}
$$

where $0 \leq \gamma_{c n} \leq 1$ is the share of the $N \operatorname{good}$ and $\rho_{c n}>0$ is the elasticity of substitution between $N$ and $T$ goods. Tradable good consumption is a composite of home and foreign tradable goods, $C_{H, t}$ and $C_{F, t}$, respectively:

$$
C_{T, t}=\left[\left(\gamma_{c h}\right)^{\frac{1}{\rho_{c h}}}\left(C_{H, t}\right)^{\frac{\rho_{c h}-1}{\rho_{c h}}}+\left(1-\gamma_{c h}\right)^{\frac{1}{\rho_{c h}}}\left(C_{F, t}\right)^{\frac{\rho_{c h}-1}{\rho_{c h}}}\right]^{\frac{\rho_{c h}}{\rho_{c h}-1}}
$$

where $0 \leq \gamma_{c h} \leq 1$ is the share of the $H$ good and $\rho_{c h}>0$ is the elasticity of substitution between $H$ and $F$ goods. Finally, let consumption of good $N$ be defined over a continuum of differentiated goods:

$$
C_{N, t}=\left[\int_{0}^{1} C_{N, t}^{\frac{\varrho-1}{\varrho}}(z) d z\right]^{\frac{\varrho}{\varrho-1}}
$$

with $\varrho>1$.

The corresponding price indices can be written as

$$
\begin{gathered}
P_{t}^{c}=\left[\left(\gamma_{c n}\right)\left(P_{N, t}\right)^{1-\rho_{c n}}+\left(1-\gamma_{c n}\right)\left(P_{T, t}\right)^{1-\rho_{c n}}\right]^{\frac{1}{1-\rho_{c n}}} \\
P_{T, t}^{c}=\left[\left(\gamma_{c h}\right)\left(P_{H, t}\right)^{1-\rho_{c h}}+\left(1-\gamma_{c h}\right)\left(P_{F, t}\right)^{1-\rho_{c h}}\right]^{\frac{1}{1-\rho_{c h}}} \\
P_{N, t}=\left[\int_{0}^{1} P_{N, t}^{1-\varrho}(z) d z\right]^{\frac{1}{1-\varrho}}
\end{gathered}
$$


where $P_{t}^{c}, P_{T, t}^{c}$, and $P_{N, t}$ are the consumer price index $(C P I)$, the consumer price index for $T$ goods, and the price index for $N$ goods, respectively.

Investment in the non-tradable and domestic tradable sectors is defined in a similar manner - a composite of $N, H$, and $F$ goods. However, we assume that shares and elasticities may differ from those of the consumption composites $^{1}$ :

$$
\begin{gathered}
I_{t}^{J}=\left[\left(\gamma_{i n}\right)^{\frac{1}{\rho_{i n}}}\left(I_{N, t}^{J}\right)^{\frac{\rho_{i n}-1}{\rho_{i n}}}+\left(1-\gamma_{i n}\right)^{\frac{1}{\rho_{i n}}}\left(I_{T, t}^{J}\right)^{\frac{\rho_{i n}-1}{\rho_{i n}}}\right]^{\frac{\rho_{i n}}{\rho_{i n}-1}}, J=N, H \\
I_{T, t}^{J}=\left[\left(\gamma_{i h}\right)^{\frac{1}{\rho_{i h}}}\left(I_{H, t}^{J}\right)^{\frac{\rho_{i h}-1}{\rho_{i h}}}+\left(1-\gamma_{i h}\right)^{\frac{1}{\rho_{i h}}}\left(I_{F, t}^{J}\right)^{\frac{\rho_{i h}-1}{\rho_{i h}}}\right]^{\frac{\rho_{i h}}{\rho_{i h}-1}}, J=N, H \\
I_{N, t}^{J}=\left[\int_{0}^{1}\left(I_{N, t}^{J}\right)^{\frac{\varrho-1}{\varrho}}(z) d z\right]^{\frac{\varrho}{\varrho-1}}
\end{gathered}
$$

with the corresponding price composites given by

$$
\begin{gathered}
P_{t}^{i}=\left[\left(\gamma_{i n}\right)\left(P_{N, t}\right)^{1-\rho_{i n}}+\left(1-\gamma_{i n}\right)\left(P_{T, t}\right)^{1-\rho_{i n}}\right]^{\frac{1}{1-\rho_{i n}}} \\
P_{T, t}^{i}=\left[\left(\gamma_{i h}\right)\left(P_{H, t}\right)^{1-\rho_{i h}}+\left(1-\gamma_{i h}\right)\left(P_{F, t}\right)^{1-\rho_{i h}}\right]^{\frac{1}{1-\rho_{i n}}} \\
P_{N, t}=\left[\int_{0}^{1} P_{N, t}^{1-\varrho}(z) d z\right]^{\frac{1}{1-\varrho}}
\end{gathered}
$$

\subsection{Households}

\subsubsection{Preferences and Decision Problem}

The preferences of the representative consumer are given by

$$
U=E_{t} \sum_{i=0}^{\infty} \beta^{i}\left\{\log C_{t+i}-\ell \frac{\left(H_{t+i}^{s}\right)^{1+\eta_{H}}}{1+\eta_{H}}+\chi_{m} \frac{\left(\frac{M_{t+i}}{P_{t+i}^{c}}\right)^{1-1 / \zeta}}{1-1 / \zeta}\right\}
$$

where $H_{t}^{s}$ is the labor supply ${ }^{2}$ :

$$
H_{t}^{s}=H_{t}^{N}+H_{t}^{H}
$$

\footnotetext{
${ }^{1}$ From now on, unless otherwise indicated, the superscript represents the sector.

${ }^{2}$ We are implicitly assuming perfect substitution between hours worked in the $N$ and $H$ sectors, $H_{t}^{N}$ and $H_{t}^{H}$, respectively.
} 
$\eta_{H}$ is the inverse of the labor supply elasticity, $\frac{M_{t}}{P_{t}^{c}}$ are real money balances, and $\zeta$ is the elasticity of substitution of real money balances.

Let $W_{t}^{N}\left(W_{t}^{H}\right)$ denote the nominal wage in the $N(H)$ sector, $e_{t}$ the nominal exchange rate, $B_{t}\left(B_{t}^{*}\right)$ holdings of discount bonds denominated in domestic (foreign) currency, $v_{t}\left(v_{t}^{*}\right)$ the corresponding price, $R_{t}^{N}\left(R_{t}^{H}\right)$ the real return to capital rented to firms in the $N(H)$ sector, $\Pi_{t}$ nominal profits from the ownership of firms in the monopolistically competitive $N$ sector, and $T_{t}$ nominal government lump-sum taxes. The household's budget constraint is given by

$$
\begin{array}{r}
P_{t}^{c} C_{t}+e_{t} B_{t}^{*} v_{t}^{*}+B_{t} v_{t}+P_{t}^{i} I_{t}^{N}+P_{t}^{i} I_{t}^{H}+M_{t}=W_{t}^{H} H_{t}^{H}+W_{t}^{N} H_{t}^{N}+ \\
e_{t} B_{t-1}^{*}+B_{t-1}+M_{t-1}+P_{N, t} R_{t}^{N} K_{t-1}^{N}+P_{H, t} R_{t}^{H} K_{t-1}^{H}+\Pi_{t}-T_{t}
\end{array}
$$

The household's revenues come from supplying labor and renting capital to firms in the $N$ and $H$ sectors, from holding domestic money, from interests from domestic/foreign bonds, and from profits from firms in the $N$ sector. These revenues are then used to consume, invest, carry money to the next period, and purchase domestic/foreign bonds.

The household is assumed to maximize the inter-temporal utility function (12) subject to (1), (2), (3), (7), (8), (9), (13), (14), and the law of accumulation of the capital stocks:

$$
\begin{aligned}
& K_{t}^{N}=\Phi\left(\frac{I_{t}^{N}}{K_{t-1}^{N}}\right) K_{t-1}^{N}+(1-\delta) K_{t-1}^{N} \\
& K_{t}^{H}=\Phi\left(\frac{I_{t}^{H}}{K_{t-1}^{H}}\right) K_{t-1}^{H}+(1-\delta) K_{t-1}^{H}
\end{aligned}
$$

We are assuming here that capital, contrary to labor, is immobile across sectors. Capital accumulation incurs adjustment costs, with $\Phi^{\prime}(\bullet)>0$ and $\Phi^{\prime \prime}(\bullet)<0$

\subsubsection{Optimality Conditions}

The first order conditions for bond holdings, consumption, labor supply, and investment are reasonably standard:

Euler equation

$$
\lambda_{t}^{C}=\beta E_{t}\left\{\lambda_{t+1}^{C}\left(1+i_{t}\right) \frac{P_{t}^{c}}{P_{t+1}^{c}}\right\}
$$


where $\lambda_{t}^{C}=\frac{1}{C_{t}}$ is the marginal utility of total consumption and $\left(1+i_{t}\right)=\frac{1}{v_{t}}$.

Uncovered interest parity condition

$$
E_{t}\left\{\lambda_{t+1}^{C} \frac{P_{t}^{c}}{P_{t+1}^{c}}\left[\left(1+i_{t}\right)-\left(1+i_{t}^{*}\right) \frac{e_{t+1}}{e_{t}}\right]\right\}=0
$$

Intra-temporal consumption allocations

$$
\begin{aligned}
C_{N, t} & =\frac{\gamma_{c n}}{1-\gamma_{c n}}\left(\frac{P_{T, t}^{c}}{P_{N, t}}\right)^{\rho_{c n}} C_{T, t} \\
C_{H, t} & =\frac{\gamma_{c h}}{1-\gamma_{c h}}\left(\frac{P_{F, t}}{P_{H, t}}\right)^{\rho_{c h}} C_{F, t}
\end{aligned}
$$

Labor supply

$$
\begin{aligned}
& \lambda_{t}^{C} \frac{W_{t}^{N}}{P_{t}^{c}}=\ell\left(H_{t}\right)^{\eta_{H}} \\
& \lambda_{t}^{C} \frac{W_{t}^{H}}{P_{t}^{c}}=\ell\left(H_{t}\right)^{\eta_{H}}
\end{aligned}
$$

Eqs. (21) and (22) imply that $\frac{W_{t}^{N}}{P_{t}^{c}}=\frac{W_{t}^{H}}{P_{t}^{c}}$.

Inter-temporal investment choice

$$
\begin{aligned}
\lambda_{t}^{C} \frac{P_{t}^{i}}{P_{t}^{c}} Q_{t}^{J}= & \beta E_{t}\left\{\lambda_{t+1}^{C}\left(\frac{P_{J, t+1}}{P_{t+1}^{c}} R_{t+1}^{J}\right)+\lambda_{t+1}^{C} \frac{P_{t+1}^{i}}{P_{t+1}^{c}} Q_{t+1}^{J}\left[\Phi\left(\frac{I_{t+1}^{J}}{K_{t}^{J}}\right)\right.\right. \\
& \left.\left.-\frac{I_{t+1}^{J}}{K_{t}^{J}} \Phi^{\prime}\left(\frac{I_{t+1}^{J}}{K_{t}^{J}}\right)+(1-\delta)\right]\right\}, J \text { is } N, H
\end{aligned}
$$

where $Q_{t}^{J}$ is Tobin's $\mathrm{Q}$ and is defined as

$$
Q_{t}^{J}=\left[\Phi^{\prime}\left(\frac{I_{t}^{J}}{K_{t-1}^{J}}\right)\right]^{-1} J=N, H
$$

Intra-temporal investment allocations;

$$
\begin{aligned}
& I_{N, t}^{J}=\frac{\gamma_{i n}}{1-\gamma_{i n}}\left(\frac{P_{T, t}^{i}}{P_{N, t}}\right)^{\rho_{i n}} I_{T, t}^{J}, J=N, H \\
& I_{H, t}^{J}=\frac{\gamma_{i h}}{1-\gamma_{i h}}\left(\frac{P_{F, t}}{P_{H, t}}\right)^{\rho_{i h}} I_{F, t}^{J}, J=N, H
\end{aligned}
$$

Since we restrict our attention to monetary regimes where either the nominal exchange rate or the nominal interest rate is the policy instrument, money demand plays no role other than pinning down the nominal money stock. We therefore omit the FOC for real money balances. 


\subsection{Firms}

\subsubsection{Non-tradable $(N)$ Sector}

The non-tradable sector is populated by a continuum of monopolistically competitive firms owned by consumers. Each firm $z \in[0,1]$ combines labor and capital according to the production function:

$$
Y_{N, t}(z)=A_{t}^{N}\left[K_{t-1}^{N}(z)\right]^{\alpha_{n}}\left[H_{t}^{N}(z)\right]^{1-\alpha_{n}}
$$

where $A_{t}^{N}$ is a productivity parameter. Cost minimization gives the standard factor demands:

$$
\begin{gathered}
\frac{W_{t}^{N}}{P_{N, t}}=M C_{t}^{N}(z)\left[1-\alpha_{n}\right] \frac{Y_{N, t}(z)}{H_{t}^{N}(z)} \\
R_{t}^{N}=M C_{t}^{N}(z) \alpha_{n} \frac{Y_{N, t}(z)}{K_{t-1}^{N}(z)}
\end{gathered}
$$

where $M C_{t}^{N}(z)$ is the real marginal cost for firm $z$.

Given the first order conditions (28), (29) and the aggregate demand schedule $Y_{N, t}(z)=\left[\frac{P_{N, t}(z)}{P_{N, t}}\right]^{-\varrho} Y_{N, t}$ the firm maximizes expected discounted profits by choosing the optimal price $P_{N, t}(z)$. We assume a Calvo [5] pricing rule, with $(1-\vartheta)$ being the probability of being able to reset the price in each period. Aggregation over firms and log-linear approximation gives a forward-looking Phillips curve for non-tradable goods inflation:

$$
\pi_{N, t}=\lambda m c_{t}^{N}+\beta E_{t} \pi_{N, t+1}
$$

where

$$
\lambda=\frac{(1-\vartheta)(1-\beta \vartheta)}{\vartheta}
$$

\subsubsection{Domestic Tradable $(H)$ Sector}

The tradable good $H$ is produced both at home and abroad in a perfectly competitive environment, where the Law of One Price holds:

$$
P_{H, t}=e_{t} P_{H, t}^{*}
$$

Domestic producers combine an imported intermediate good, $X_{M, t}$, and domestic value added, $V_{H, t}$, according to the production function:

$$
Y_{H, t}=\left[\left(\gamma_{v}\right)^{\frac{1}{\rho_{v}}}\left(V_{H, t}\right)^{\frac{\rho_{v}-1}{\rho_{v}}}+\left(1-\gamma_{v}\right)^{\frac{1}{\rho_{v}}}\left(X_{M, t}\right)^{\frac{\rho_{v}-1}{\rho_{v}}}\right]^{\frac{\rho_{v}}{\rho_{v}-1}}
$$


Domestic value added is produced using labor and sector-specific capital as inputs:

$$
V_{H, t}=A_{t}^{H}\left(K_{t-1}^{H}\right)^{\alpha_{h}}\left(H_{t}^{H}\right)^{1-\alpha_{h}}
$$

where $A_{t}^{H}$ is a technology parameter.

Cost minimization gives the factor demands:

$$
\begin{gathered}
\frac{W_{t}^{H}}{P_{H, t}}=\left(1-\alpha_{h}\right)\left(\gamma_{v}\right)^{\frac{1}{\rho_{v}}} \frac{V_{H, t}}{H_{t}^{H}}\left(\frac{Y_{H, t}}{V_{H, t}}\right)^{\frac{1}{\rho_{v}}} \\
R_{t}^{H}=\alpha_{h}\left(\gamma_{v}\right)^{\frac{1}{\rho_{v}}} \frac{V_{H, t}}{K_{t-1}^{H}}\left(\frac{Y_{H, t}}{V_{H, t}}\right)^{\frac{1}{\rho_{v}}} \\
\frac{P_{M, t}}{P_{H, t}}=\left(1-\gamma_{v}\right)^{\frac{1}{\rho_{v}}}\left(\frac{Y_{H, t}}{X_{M, t}}\right)^{\frac{1}{\rho_{v}}}
\end{gathered}
$$

where $P_{M, t}$ is the price of the imported intermediate good.

\subsection{Foreign Sector}

The Law of One Price is assumed to hold for foreign goods $F$ and $M$, i.e.

$$
\begin{gathered}
P_{F, t}=e_{t} P_{F, t}^{*} \\
P_{M, t}=e_{t} P_{M, t}^{*}
\end{gathered}
$$

The terms of trade and the real exchange rate are defined as follows:

$$
\begin{gathered}
S_{F, t}=\frac{P_{F, t}}{P_{H, t}} \\
S_{M, t}=\frac{P_{M, t}}{P_{H, t}} \\
q_{t}^{c}=\frac{P_{T, t}^{c}}{P_{N, t}}
\end{gathered}
$$

Following Schmitt-Grohe and Uribe [39] the nominal interest rate at which households can borrow internationally is given by the world interest rate $\tilde{\imath}^{*}$ plus a premium, which is assumed to be increasing in the real value of the country's stock of foreign debt:

$$
\left(1+i_{t}^{*}\right)=\left(1+\tilde{\imath}_{t}^{*}\right) g\left(-B_{H, t}\right)
$$

where $B_{H, t}=\frac{e_{t} B_{t}^{*}}{P_{H, t}}$ and $g(\cdot)$ is a positive, increasing function. Eq. (43) ensures the stationarity of the model. 


\subsection{Government Budget Constraint}

Government expenditures are financed by lump-sum taxes and money creation. We also assume that the government is required to balance the budget at every point in time, i.e.

$$
P_{H, t} G_{H, t}+P_{N, t} G_{N, t}=M_{t}-M_{t-1}+T_{t}
$$

\subsection{Monetary Policy}

We assume that the domestic monetary authority follows an open-economy version of the Taylor rule:

$$
\frac{\left(1+\bar{i}_{t}\right)}{\left(1+i^{s s}\right)}=\left(\frac{1+\pi_{t}^{c}}{1+\pi_{S S}}\right)^{\omega_{\pi^{c p i}}}\left(\frac{1+\pi_{t}^{N}}{1+\pi_{S S}^{N}}\right)^{\omega_{\pi^{n}}}\left(\frac{e_{t}}{e^{s s}}\right)^{\omega_{e}}
$$

where $\omega_{\pi^{c p i}}, \omega_{\pi^{n}}, \omega_{e} \geq 0$ are the feedback coefficients to CPI inflation, nontradable inflation, and nominal exchange rate, respectively. Here $\left(1+\bar{i}_{t}\right)$ is the target short-term interest rate, $\left(1+\pi_{t}^{c}\right)$ is CPI inflation at time $t$, $\left(1+\pi_{t}^{N}\right)$ is non-tradable inflation at time $t$, and $\left(1+\pi_{S S}\right),\left(1+\pi_{S S}^{N}\right)$, and $e^{s s}$ are the steady state values of CPI inflation, non-tradable inflation, and nominal exchange rate.

The choice of the parameters $\omega_{\pi^{c p i}}, \omega_{\pi^{n}}$, and $\omega_{e}$ allows us to specify alternative monetary policies. $\omega_{\pi^{c p i}}>0\left(\omega_{\pi^{n}}>0\right)$ implies that the Central Bank is responding to positive deviations of CPI (non-tradable) inflation from the target. $\omega_{e}>0$ indicates that the central bank engages in exchange rate management by reacting to deviations of $e_{t}$ from the target level of $e^{s s}$. The higher the feedback parameters, the more aggressively the Central Bank is responding to such deviations. A fixed exchange rate regime can be expressed as the limiting case $\omega_{e} \rightarrow \infty$. While Taylor rules including the output gap among the feedback variables could be welfare-improving, we focus on policy rules of the form (45) since the EU accession criteria force the policy-maker to face an explicit trade-off between the objectives of inflation and exchange rate stabilization.

We also assume interest rate smoothing, so that the domestic short-term interest rate at time $t$ is equal to

$$
\left(1+i_{t}\right)=\left[\left(1+\bar{i}_{t}\right)\right]^{(1-\chi)}\left[\left(1+i_{t-1}\right)\right]^{\chi} \varepsilon_{t}^{m p}
$$

where $\chi \in[0,1)$ is the degree of smoothing and $\varepsilon_{t}^{m p}$ is an exogenous shock to monetary policy. 


\subsection{Equilibrium}

The resource constraint in the non-tradable and domestic tradable sector are given by

$$
\begin{gathered}
Y_{N, t}=C_{N, t}+I_{N, t}^{N}+I_{N, t}^{H}+G_{N, t} \\
Y_{H, t}=A B_{H, t}+C_{H, t}^{*}
\end{gathered}
$$

where $A B_{H, t}$, given by

$$
A B_{H, t}=C_{H, t}+I_{H, t}^{N}+I_{H, t}^{H}+G_{H, t}
$$

is domestic absorption and $C_{H, t}^{*}$ are net exports of the $H$ good.

The trade balance, expressed in units of good $H$, can be written as

$$
N X_{H, t}=C_{H, t}^{*}-\frac{P_{F, t}}{P_{H, t}}\left(C_{F, t}+I_{F, t}^{N}+I_{F, t}^{H}\right)-\frac{P_{M, t}}{P_{H, t}} X_{M, t}
$$

Assuming that domestic bonds are in zero net supply, the current account (in nominal terms) reads as

$$
e_{t} B_{t}^{*}=\left(1+i_{t-1}^{*}\right) e_{t} B_{t-1}^{*}+P_{H, t} N X_{H, t}
$$

Finally, labor market clearing requires

$$
H_{t}^{d}=H_{t}^{N}+H_{t}^{H}=H_{t}^{s}
$$

\section{Model Parametrization}

The model is solved by finding the Rational Expectations Equilibrium of the log-linearized equations around the steady state. The key equations are described in the Appendix. The model is calibrated using data for the Czech Republic obtained from the Czech Statistical Office and the International Financial Statistics of the IMF.

\subsection{Preferences}

The quarterly discount factor $\beta$ is set equal to 0.99 , which implies a real world interest rate of 4 percent in a steady state with zero inflation. We choose $\eta_{H}$ to be 2 , implying an elasticity of labor supply equal to $\frac{1}{2}$, and fix average hours worked relative to total hours available equal to $\frac{1}{3}$. The elasticity of substitution between tradable and non-tradable goods in the consumption index, $\rho_{c n}$, is taken from Stockman and Tesar [40] and set 
equal to 0.5. The elasticity of substitution between foreign and domestic goods in the tradable consumption index, $\rho_{c h}$, is set equal to 1.5 following the international RBC literature. The share of non-tradable goods in total consumption, $\gamma_{c n}$, is 0.45 . This corresponds to the weight of non-tradable goods in the Czech $\mathrm{CPI}^{3}$. Combined with the relevant technology parameters below, the share of domestic goods in the tradable consumption index, $\gamma_{c h}$, is chosen to match the average ratio of consumption-to-GDP over the period 1990-2001 - about 0.52.

\subsection{Technology}

We assume there are no capital adjustment costs in steady state. The elasticity of Tobin's Q with respect to the investment-capital ratio is taken to be 0.5 . The quarterly depreciation rate of capital, $\delta$, is assigned the conventional value of 0.025 . In the absence of direct evidence of the labor shares in the two sectors, we follow Cooks and Devereux [12] and assume that the tradable sector is more capital-intensive than the non-tradable sector. For simplicity, we consider the case of $\alpha_{h}=0.67$ and $\alpha_{n}=0.33$. In the absence of a direct estimate for the Czech Republic, we follow standard estimates and set the steady state mark-up in the non-tradable sector equal to 1.1. The elasticity of substitution $\rho_{v}$ between the imported intermediate good, $X_{M, t}$, and domestic value added, $V_{H, t}$, is set equal to 0.5. Even though we don't have an estimate for this parameter, we think it is reasonable to assume a low value, given the trade structure of the Czech Republic. The elasticity of substitution between tradable and non-tradable goods in total investment, $\rho_{i n}$, and the elasticity of substitution between foreign and domestic goods in the tradable component of investment, $\rho_{i h}$, are assigned the same values of the corresponding consumption indexes. The share of non-tradable goods in the investment index $I_{t}^{J}, \gamma_{i n}$, is chosen such that the ratio of investment to GDP is roughly 0.3 and the share of non-tradable goods to GDP is 0.56 - based on our estimates for the Czech Republic ${ }^{4}$. The share of domestic goods in the tradable component of investment, $\gamma_{i h}$, and the share of domestic value added in the domestic tradable sector, $\gamma_{v}$, are chosen such that, in a balanced-trade steady state with unitary terms of trade, the commodity composition of imports matches, as close as possible,

\footnotetext{
${ }^{3}$ See Inflation Report, July 2002, Czech National Bank.

${ }^{4}$ Source: "Czech republic: Selected Issues and Statistical Appendix", IMF Country Report No. 02/168, August 2002. We use data for 1997-2001, GDP by origin. In the non-tradable sector we include the following categories: construction; wholesale and retail trade, restaurants and hotels; services.
} 
the available data for the Czech Republic ${ }^{5}$. As far as the degree of nominal rigidities in the non-tradable sector, in the absence of direct estimates we assume the unconditional probability $\vartheta$ of non-adjusting prices in period $t$ equal to 0.85 .

\subsection{Government Policy}

The steady state ratio of government expenditure to output, $\frac{G_{J}}{Y_{J}}$, for $J=$ $H, N$, is assumed to be equal to 10 percent.

We consider four alternative exchange rate regimes: (1) Fixed exchange rate, by setting an arbitrary large value to $\omega_{e} ;(2)$ CPI inflation targeting ${ }^{6}$, by setting $\omega_{\pi^{c p i}}=2$; (3) CPI inflation targeting with managed exchange rate, by setting $\omega_{\pi^{c p i}}=2$ and $\omega_{e}>0$; and (4) Non-tradable inflation targeting, by setting $\omega_{\pi^{n}}=2$. The interest rate smoothing parameter is assigned the value of 0.8. These values are consistent with estimates of inflation-based Taylor rules for OECD open economies (see Ravenna [36] and Clarida et al. [11]).

\section{The Balassa-Samuelson Effect and the Choice of Exchange Rate Regime}

This section examines the impact of a persistent increase in the rate of growth of the tradable sector productivity under alternative exchange rate regimes. We investigate under which exchange rate regime the small open economy is able to meet the Maastricht convergence criteria, under the assumption that the only force driving the business cycle is steady productivity growth. In the next section we examine the behaviour of the economy when the business cycle is driven by a full set of shocks.

\footnotetext{
${ }^{5}$ Source: "Czech republic: Selected Issues and Statistical Appendix", IMF Country Report No. 02/168, August 2002. We use data for 1997-2001, Commodity Composition of Imports. We classify "Machinery and transport equipment" as capital goods, corresponding to the share $\left(1-\gamma_{i h}\right)$. We classify "Crude materials inedible, except fuels", "Minerals, fuels, lubrificants, and related materials", "Chemicals", "Manufactured goods", and 50 percent of "Miscellaneous manufactured articles" as intermediate goods, corresponding to the share $\left(1-\gamma_{v}\right)$. Finally, we classify the remaining categories as consumption, corresponding to $\left(1-\gamma_{c h}\right)$. This implies that capital goods are less than 40 percent, intermediate inputs more than 50 percent, and consumption about 10 percent of imports.

${ }^{6}$ We refer to inflation-based instrument policy rules as inflation targeting monetary regimes. However, there is considerable controversy about the operational definition of inflation targeting.
} 
The Balassa-Samuelson (B-S) shock is constructed as follows. We assume that the relative productivity of the tradable sector $\left(A_{H} / A_{N}\right)_{t}$ grows at decreasing rates for 10 years, until it reaches a new stationary level. Over the 10 years, the average growth rate of the sectoral productivity differential is 2.65 percent per year ${ }^{7}$. No other productivity shock affects the economy in subsequent periods; the initial shock at $t=0$ generates the entire dynamics, which is expected by the forward-looking agents from $t=1 \mathrm{on}$. Without loss of generality, we assume that there is no productivity growth differential between the Euro area and the candidate countries' non tradable sector.

\subsection{Fixed vs Floating Exchange Rate Regimes}

Figure 2 shows the impact of the B-S shock under two alternative regimes. Consider a fixed exchange rate first. Productivity gains in the domestic tradable sector generate a large appreciation of the real exchange rate. Since the nominal exchange rate is fixed, high inflation in the non-tradable sector pushes CPI inflation up, well beyond the inflation criterion limit. The shock generates an initial surge in non-tradable inflation - as the steady productivity growth is anticipated after time 0 - and, as a consequence, in the CPI inflation rate. In the following periods the inflation rate decreases slowly (due to price stickiness) to a long-term level of about 2 percent. The B-S effect requires that the relative price of tradable to non-tradable goods - the real exchange rate - decreases according to the relative productivity in the two sectors. Since the price of the tradable good is determined in the world market and the nominal exchange rate is fixed, this can only be achieved via a steady increase in the price of the non-tradable goods. This explains the long-term impact of the shock on the CPI inflation - which lasts for as long as the relative productivity of the tradable sector is increasing. The real interest rate drops, stimulating investment and consumption. The rise in consumption of tradable goods is financed from abroad, as shown by the initial drop in the production of good $H$ and by the growing foreign indebtedness. This is an important feature of the model, as EU candidate countries are actually experiencing - or have already experienced - a consumption boom and are running substantial current account deficits. Given the low degree of intra-temporal substitution, both tradable and non-tradable consumption rise, even though the price of non-tradable goods is higher. Output in the non-tradable sector grows, driven by the boom in aggregate demand. Out-

\footnotetext{
${ }^{7}$ The implicit assumption is that the 2.65 percent productivity growth is relative to a zero-growth in the Euro area. We can always re-interpret this as excess productivity growth relative to the Euro area.
} 
put in the domestic tradable sector, after an initial drop, starts growing to take advantage of the increased productivity ${ }^{8}$.

Consider now a flexible exchange rate regime. The figure shows the case of a policy-maker targeting the CPI inflation rate by adopting the rule

$$
i_{t}=\chi i_{t-1}+(1-\chi) \omega_{\pi^{c p i}} \pi_{t}
$$

with $\chi=0.8, \omega_{\pi^{c p i}}=2$. Since the nominal exchange rate is now allowed to appreciate, the initial effect on the CPI inflation is negative, driven by a drop in the tradable component of inflation and a smaller jump in nontradable inflation rate. After the initial period, the long-term inflation rate is positive but smaller than under a fixed exchange rate ${ }^{9}$. The reduction of the real interest rate is smaller, when compared to the fixed exchange rate regime, and correspondingly smaller is the increase in consumption and investment. The increase in non-tradable sector output is reduced by over 40 percent.

The main result is that, by adopting an inflation targeting regime, the central bank is able to keep CPI inflation within the limit set by the Maastricht criteria. However, by disregarding the behavior of the nominal exchange rate beyond the effect on the inflation rate, the central bank fails to constrain the trend appreciation of the currency. After two years the nominal exchange rate has appreciated by approximately 10 percent. The economy might still be able to comply with the ERM-II exchange rate criterion, but since the nominal exchange rate is bound to exceed the lower threshold of the band (not shown in figure), the country is exposed to the danger of a currency attack. Moreover, it can be shown that the more aggressive the central bank is in pursuing a reduction of inflation, the quicker the nominal exchange rate approaches the threshold.

\footnotetext{
${ }^{8}$ Two features of the model explain this pattern. First, intra-temporal substitutability between tradables and non-tradables is limited. Households can increase their total consumption by shifting resources to the non-tradable sector and by importing the tradable good. In a model where they could not import good $\mathrm{H}$, they would have to increase production of both goods. Second, productivity in the tradable sector is expected to grow. Households therefore can safely accumulate foreign debt to increase consumption today, since they will repay the debt using the tradable good $\mathrm{H}$, whose future cost will decrease over time relative to non tradable goods.

${ }^{9}$ The impulse response shows the deviation from the steady state inflation rate, which we assume equal to the Euro area inflation rate. Since the nominal exchange rate in this regime is completely flexible - e.g. the economy can have a steady state appreciation rate against the foreign currency - the policy maker could effectively choose any steady state inflation by changing its steady state money supply policy. This is not the case whenever the nominal exchange rate is managed, since that would require stationarity in the level of the exchange rate rather than in the depreciation/appreciation rate.
} 


\subsection{Compliance with the EU Accession Requirements}

Is there a balance between stabilizing the CPI inflation rate and controlling the exchange rate movements? What the policy maker can do - regardless of the consequences on the real economy - is to allocate the effects of the B-S shock between CPI inflation and nominal exchange rate. Monetary policy alone cannot reduce the B-S effect. Figure 3 shows the response of the economy when the monetary authority reacts to fluctuations of both the CPI and the nominal exchange rate. The parameters in the policy rule are set equal to $\chi=0.8, \omega_{\pi^{c p i}}=2, \omega_{e}=0.025, \omega_{\pi^{n}}=0$. A rule that assigns even a small feedback coefficient to the exchange rate can satisfy the ERM-II requirement by considerably slowing the nominal exchange rate appreciation to less than 10 percent in the first five years after the shock. At the same time, the CPI inflation drops to a long-term value just above 2 percent, and not much higher in the early years after the shock. As the next section will show, however, once we allow for other shocks to hit the economy the probability of satisfying the Maastricht inflation criterion when managing the exchange rate is very small.

Consider now the case of non-tradable inflation targeting. As emphasized by Devereux and Lane [19] and Benigno [3] in the context of simpler stylized open-economy models, in the presence of nominal rigidities in the non-tradable sector, the optimal policy maker should aim at stabilizing the price of non-tradable goods. Figure 4 shows the response of the economy under the policy rule described by the parameters $\chi=0.8, \omega_{\pi^{n}}=2$, $\omega_{e}=\omega_{\pi^{c p i}}=0$. This rule still allows for variations in relative prices since the nominal exchange rate is free to fluctuate and to adjust to shocks. Monetary policy is effective in controlling non-tradable inflation and therefore CPI inflation - in this case CPI inflation actually drops substantially on impact. The real interest rate rises slightly and output in the non-tradable sector expands slowly. However, the appreciation of the real exchange rate translates entirely into an appreciation of the nominal exchange rate, which leads to a violation of the exchange rate requirement. The intuition for the result is that, for the B-S effect not to generate a trend appreciation in the nominal exchange rate, the price of non-tradable goods ought to increase relative to the price of the domestic tradable goods. Since the latter is fixed on world markets, the CPI inflation will also have to increase. Targeting CPI or non-tradable price inflation therefore generates a similar trend movement in the nominal exchange rate.

In terms of robustness of these results, it must be stressed that, when

the elasticity of substitution between tradable and non-tradable goods in 
consumption and investment, $\rho_{c n}$ and $\rho_{i n}$ respectively, is high, then the increase in non-tradable inflation is smaller. As a consequence, also CPI inflation is smaller and the difference between fixed and flexible rates is less pronounced.

Buiter and Grafe [4] suggest re-defining the Maastricht inflation criterion in terms of a basket of tradable goods to take into account the B-S-induced CPI differential. But from the Law of One Price, eq. (32), the (log-linear) tradable-good basket inflation differential $\left(\pi_{T}-\pi_{T}^{*}\right)$ is equal to the nominal exchange rate depreciation rate $\Delta e_{t}$. Any inflation criterion specified in terms of tradable goods inflation is really an exchange rate criterion.

\section{Balassa-Samuelson Effect and Capital Inflows}

In November 2002 the rating agency Moody's upgraded the foreign currency ratings of the eight ex-communist countries planning to join the EMU to the same level as the existing ratings on local currency government bonds. The justification for the move was Moody's belief that the EU accession process is virtually irreversible, thereby reducing the risk of a foreign currency crisis in these countries.

The literature on EU enlargement often raises concerns about (excessive) capital inflows, which might expose accession countries to potentially large and dangerous capital flow reversals. We argue that a large share of capital inflows is related to productivity growth rather than to exogenous and possibly temporary factors such as a reduction in the country risk premium.

Toward this end, consider a temporary but persistent unanticipated one hundred basis points reduction in the foreign interest rate described by an $\operatorname{AR}(1)$ process with autocorrelation coefficient $\rho_{i^{*}}=0.95$ - a shock that can be interpreted as a reduction in the sovereign risk premium for the country. Figure 5 shows the dynamics of the economy for two different policies. In the case of a fixed exchange rate regime, the economy borrows from abroad but the appreciation of the real exchange rate is small. As the nominal exchange rate is prevented from appreciating and the domestic nominal interest rate falls, price stickiness causes a large drop in the real interest rate, fueling a rise in consumption and investment. Output in the non-tradable sector increases, generating persistent but low inflation in the first six quarters. On the contrary, output in the domestic tradable sector drops. Consumption smoothing behavior can explain this pattern. As the real interest rate drops, current consumption is substituted for future consumption. But the limited

substitutability between goods implies that households would like to increase 
consumption of all goods in similar proportions. Taking this intra-temporal smoothing into account, the largest (optimal) increase in consumption is delivered by an increase in production in the non-tradable sector and an increase in imports of the (traded) $H$ and $F$ goods.

The domestic nominal interest rate, after 5 years, has increased nearly all the way back to the steady state level. The corresponding foreign interest rate reverts more slowly. The difference between the two - which are expected to behave symmetrically in a fixed exchange rate regime - stems from the presence of an endogenous risk premium, described in eq. (43). We assume that for every 10 percent increase in the ratio of net foreign debt to steady state GDP, the interest rate at which domestic agents can borrow abroad increases by 0.4 percent, a conservative figure for emerging countries. The endogenous risk premium creates a wedge between $i$ and $i^{*}$, limiting the level of foreign indebtedness that domestic agents will optimally choose.

Assume now that the central bank adopts the CPI inflation targeting rule defined in eq. (53). As figure 5 shows, the nominal exchange rate appreciates together with the real exchange rate. CPI inflation drops, as both the tradable and the non-tradable inflation are lower. The real interest rate drops by much less than under the fixed exchange rate case. The increase in consumption and investment is therefore less pronounced.

Compare now the capital inflows generated by the reduction in the risk premium with the inflows linked to the B-S effect. Regardless of the exchange rate regime, after one year the productivity-driven inflows are about eight times larger. Moreover, while the inflows related to a lower risk premium reach a peak shortly afterwards, the inflows related to the B-S effect continue to grow, due to the "long-term" nature of the shock.

Over a medium-term horizon, the share of capital flows to EU candidate countries related to productivity gains can be expected to be larger than the share linked to exogenous factors such as volatility in risk premia. Given productivity-driven capital inflows are less volatile and more resilient to short-term financial distress, large current account deficits and high borrowing levels are unlikely to expose EU candidate countries to the dangers associated with large unbalanced portfolio build-ups typical of emerging market economies.

\section{$7 \quad$ Variance Trade-offs}

The previous section discussed how productivity growth in the tradable sector of EU candidate countries affects the level of inflation and nominal 
exchange rate during the accession process. In this section we allow for other business cycle shocks to affect the dynamics of the economy. We then examine the inflation/exchange rate and inflation/output gap variance trade-offs conditional on a simple Taylor rule under alternative exchange rate regimes.

We derive two sets of results. First, the B-S effect reduces the probability of complying with the EMU accession requirements. Second, the B-S effect also has an impact on the volatility of the macroeconomic variables. This in turn affects the choice of the optimizing policy-maker and the constraints that the Maastricht criteria impose on this choice. Since the variance tradeoffs are derived from a general equilibrium model, we can also evaluate the consequences of modifying the EMU accession criteria for the policy choice of the candidate countries - within the class of the simple policy rules examined.

\subsection{Model Calibration}

To build the variance trade-off plots we need to make assumptions about the shocks that drive the dynamics of the economy and about their forcing processes. Examples of dynamic stochastic general equilibrium models calibrated on Eastern European countries are scarce (see Mahadeva and Smidkova [27] for a semi-structural model of the Czech republic). Two issues arise that are specific to formerly-planned economies. First, the span of data available to calibrate the model is very short - these countries left the Soviet bloc after 1990, and some did not even exist before that date. Second, using data from the early 90 s is likely to lead to spurious results, since in the early 90s these countries underwent a transition toward market economy institutions. Thus, the business cycle behavior, as measured since the early $90 \mathrm{~s}$, is not likely to be representative of the future dynamics of these economies.

Given these caveats, we estimate the stochastic processes driving the model using post-1994 data, when possible. When this is not possible, we calibrate the shocks by evaluating the fit of the model moments, as common in the RBC literature. All data are taken from the 2002 third quarter release of the IMF International Financial Statistics, OECD Main Economic Indicators, Eurostat and Czech Republic Statistical Office data bases.

Table 1 reports the standard deviations and autocorrelations of the shocks used in our calibration. The values for the tradable and non-tradable sector productivity are calibrated and are within reasonable bounds for the values used in the calibration of RBC models. We assume that the entire 
government demand is for goods produced by the non-tradable sector. The government demand shock is estimated from the (H-P filtered) public consumption series. The parameters for the foreign $H$ inflation, foreign $F$ price and foreign $M$ intermediate price are calibrated. Estimates from aggregated series are not possible since we would need to know the covariance between the prices. We hope, in the future, to use disaggregated data to calibrate these processes, since they enter prominently in the determination of the CPI behaviour. The foreign interest rate parameters are obtained from the Euro-denominated 3-month German bond (a riskless rate). The policy rule implies a strong degree of interest rate smoothing, as found in most estimates of policy rules for OECD economies. The Central Bank is assumed to react to deviations of the current inflation and exchange rate from their steady state values.

Table 2 shows the performance of the model in terms of second moments and compares these to the values obtained from the data. A second column, for comparison purposes, shows data for the G-7 countries business cycle over a longer time-span post-Bretton Woods. The model performs well in terms of cross correlations, while lacks in some dimensions in mimicking the volatility of the economy. The GDP is less volatile in the model although this is partly expected since the model's real GDP is evaluated at consumer rather than producer prices. Consumption is too volatile, while the investment high variability in the data is matched. The nominal interest rate has been more volatile in the Czech Republic. But part of this volatility is attributable to the long disinflation during the 1990s. Future volatility will be closer to the average value of the G-7 countries. The nominal exchange rate is also about $45 \%$ less volatile in the model relative to the data. The real exchange rate volatility is instead much closer to the one experienced by the Czech Republic.

\subsection{Policy Choices and Productivity Growth}

The first issue we are interested in is whether trend productivity growth affects the inflation/exchange rate trade-off. The previous section has already shown that, depending on the degree of nominal exchange rate flexibility allowed by the policy maker, either the inflation rate or the nominal exchange rate appreciation will be large. We therefore expect that a country experiencing the B-S effect will also face a higher unconditional variance in either the inflation rate or the nominal exchange rate. Figure 6 confirms this intuition. The plot shows the quarterly inflation/nominal exchange rate 
variance trade-off given the policy rule:

$$
i_{t}=\chi i_{t-1}+(1-\chi)\left[\omega_{\pi} \pi_{t}+\omega_{e} e_{t}\right]
$$

for values of the feedback coefficient $\omega_{e} \in[700,0.01]$. This range includes policy rules that keep the exchange rate virtually fixed at the steady state value and policy rules that allow a very high volatility of the exchange rate while targeting aggressively the inflation rate. The interest-smoothing coefficient $\chi$ is set equal to 0.8 . We allow for a high value of the inflation feedback coefficient $\omega_{\pi}=3.5$ to prevent the weight of the exchange rate objective from driving monetary policy for all but the smallest values of $\omega_{e}$. The dotted line plots the standard case - i.e., without the B-S shock. The solid line plots the variance trade-off under the assumptions that productivity growth in the tradable sector is going to be higher by an average of 2.65 percent per annum over the 10 year period of the simulation and that the steady state inflation rate is equal to the EU average ${ }^{10}$.

Since the shocks are normally distributed, we can compute the implied probability that a variable will fall within a given interval as a function of the variance of the variable itself. The left-most vertical line corresponds to the variance of $e_{t}$ that guarantees that the nominal exchange rate is within a \pm 2.5 percent band around the central parity in any quarter with a 95 percent probability ${ }^{11}$. Any policy rule that generates a lower variance of $e_{t}$ - points along the dotted line to the left of the vertical probability boundary - keeps the exchange rate within the band with a probability equal or higher than 95 percent. The ERM-II membership currently requires that the exchange rate stay within a \pm 15 percent band around the central parity. The second vertical line has to its left all standard deviation combinations $\left(\sigma_{e}, \sigma_{\pi}\right)$ attainable by a policy maker following the rule (54) that satisfy the ERM-II requirement in any quarter with a 95 percent probability. Below the horizontal boundary line lay all points $\left(\sigma_{e}, \sigma_{\pi}\right)$ that with 82 percent probability give a quarterly inflation rate lower than 1 percent ${ }^{12}$.

\footnotetext{
${ }^{10}$ The concave portion of the trade-off plot also represents the policy frontier for a policy-maker minimizing the loss function $L=\mathrm{E}_{t}\left\{\sum_{i=0}^{\infty}\left[\lambda e_{t+i}^{2}+\pi_{t+i}^{2}\right]\right\}$ as the preference parameter $\lambda$ changes, conditional on the policy rule (54) - the 'conditional policy frontier' of the policy-maker. See Dennis [16] for details on computation of optimal monetary policy conditional on simple rules and comparison to fully optimal policies.

${ }^{11}$ The corresponding probability that the exchange rate is within the band in all quarters over the required period of two years will be lower, and can be derived as $\operatorname{Pr}\left(e_{t} \in[-2.5 \%,+2.5 \%]\right) * \operatorname{Pr}\left(e_{t+1} \in[-2.5 \%,+2.5 \%] \mid e_{t} \in[-2.5 \%,+2.5 \%]\right) * \ldots$ up to $t+7$.

${ }^{12}$ The Maastricht Criteria sets a 1.5 percent limit for the yearly inflation rate - equivalent to an average quarterly inflation rate of about 0.4 percent. We build the variance boundary
} 
For a policy maker adopting the rule defined in (54), the plots show that there exists a range of policies allowing the economy to comply with the EMU accession requirements with a high probability. If the economy is experiencing a B-S effect, however, the variance trade-off shifts to the right and there is no policy allowing the economy to meet the ERM-II criterion and the Maastricht inflation criterion at the same probability level as in the standard case. Assume, in fact, that the policy maker aims at meeting the ERM-II criterion in any quarter with at least 95 percent probability. Then the 82 percent probability boundary shows that the combination $\left(\sigma_{e}, \sigma_{\pi}\right)$ attainable by any such policy implies a probability of a quarterly CPI inflation in excess of 1 percent non-lower than 18 percent ${ }^{13}$. Alternatively, any policy that guarantees a higher ex-ante probability of meeting the inflation criterion implies that the probability of meeting the ERM-II criterion in any quarter is lower than 95 percent ${ }^{14}$.

What are the implications of different monetary policies for the inflation/output gap trade-off? Figure 7 shows the inflation/output gap variance trade-off corresponding to the conditional policy frontiers shown in figure 6 . Since the variance trade-off in the $\left(\sigma_{y_{g a p}}, \sigma_{\pi}\right)$ space is not an efficiency frontier for the Taylor rule (54), the plot can cross over, as it happens when the exchange rate is tightly managed. A more flexible exchange rate is able to deliver both lower inflation and a lower output gap - measured as the distance between output and the flexible-price potential output. In the B-S case, the gain from exchange rate flexibility is even larger. Compare, for example, points $A-A^{\prime}, B-B^{\prime}$, and $C-C^{\prime}$. The extra cost in terms of inflation and output gap volatility due to the B-S effect becomes larger as $\omega_{e}$ increases and the exchange rate volatility gets smaller. The probability boundaries - to the right of which are attainable combinations $\left(\sigma_{y_{g a p}}, \sigma_{\pi}\right)$ that guarantees, with 95 percent probability, a given volatility of the exchange rate conditional on the Taylor rule - get further and further to the right relative

for a quarterly inflation rate of 1 percent assuming that a policy maker that wishes to stay within the yearly 1.5 percent limit is also expected to avoid inflation in any given quarter above 1 percent - equivalent to 4 percent at yearly rates.

${ }^{13}$ The probability level for the variance boundaries drawn on the picture will actually be lower in the Balassa-Samuelson case. The Balassa-Samuelson shock generates a persistent drop (appreciation) in the real exchange rate $P_{T} / P_{N}$. Therefore the distribution of CPI inflation (exchange rate) will have a positive (negative) skew relative to the Gaussian, and more probability mass for positive (negative) values of the variable. The probability level is then only an upper bound in the Balassa-Samuelson case.

${ }^{14}$ Note also that, even in the absence of the B-S effect, no policy would allow the economy to meet the Maastrich inflation criterion and keep the exchange rate within a narrow \pm 2.5 percent band against the Euro with a very high probability. 
to the standard case.

A \pm 15 percent band for the exchange rate offers a superior economic performance - under the assumption that an optimizing policy maker prefers regimes that minimize both output gap and inflation rate fluctuations. But we know from figure 6 that if the B-S effect is at work, any point in figure 7 to the right of the \pm 15 percent volatility boundary does not satisfy the inflation Maastricht criterion with a probability of at least 18 percent, conditional on the Taylor rule (54) ${ }^{15}$.

Proposals to adapt the EMU requirements to the rapid productivity growth of EU candidate countries suggest relaxing either the ERM-II mechanism or the Maastricht inflation criterion (Buiter and Grafe [4]). Figure 8 compares the inflation/output gap trade-off generated by two alternative families of policy rules. Either policy implies a violation of one of the nominal accession requirements.

The solid line plots the variance trade-off for the Taylor rule (54) as a function of $\omega_{e}$. In figure 6 we showed that this rule violates the inflation criterion with a high probability. Relaxing the inflation criterion allows the policy-maker to choose any point to the right of the probability boundary and still have a reasonable expectation to meet the exchange rate requirement.

We now compare the variance trade-off induced by the Taylor rule (54) with a monetary regime that does not explicitly limit the volatility of the exchange rate. The dashed line assumes that the policy maker follows the inflation target instrument rule:

$$
i_{t}=\chi i_{t-1}+(1-\chi) \omega_{\pi} \pi_{t}
$$

The policy maker is able to choose any point along the dashed line only if the exchange rate requirement is relaxed. Nearly all points imply a lower volatility of both output gap and inflation relative to the outcome of the policy rule (54). Within the family of policy rules examined, therefore, any modification to the accession requirements that relaxes the exchange rate requirement delivers a better economic performance. For example, compare a rule that meets the \pm 15 percent exchange rate requirement along the solid line with the rule $(55)$ for $\omega_{e}=3.5$ - the point $\left(\sigma_{y_{g a p}}, \sigma_{\pi}\right)$ where the solid line intersects the dashed line. Managing the exchange rate requires approximately a 35 percent increase in the output gap volatility and a 31

\footnotetext{
${ }^{15}$ It is noteworthy that, even in the standard case, the exchange rate requirement prevents the policy maker from adopting a policy delivering both lower inflation and lower output gap volatility.
} 
percent increase in the inflation volatility.

\section{Concluding Remarks}

Integrating Central and Eastern European countries that have recently concluded the transition from planned to market economy into the EU and the Euro currency area presents a number of challenges. This paper examines the choice of exchange rate regime in countries experiencing sustained productivity growth in the tradable sector during the process of accession to the EMU. We discuss the implication of the B-S effect within a dynamic stochastic GE model. The main results can be summarized as follows.

First, under a fixed or heavily managed exchange rate, the B-S effect might prevent compliance with the Maastricht inflation criterion. A contractionary policy restraining demand for non-tradable goods would be needed to ease the pressure on the inflation rate. Second, given the B-S effect, we show that, conditional on a simple feedback monetary policy rule, the output gap/inflation variance trade-off shifts and increases the cost of managing/fixing the exchange rate in terms of inflation or output gap variability. Third, our model allows the comparative evaluation of alternative policy rules in terms of the volatility of the economy over the business cycle. We show that policy rules allowing for more exchange rate flexibility lower the volatility of the economy in terms of both the inflation rate and the output gap.

The latter conclusion deserves further investigation. Ideally, we would like to know whether alternative accession criteria could prevent EU candidate countries from adopting inappropriate monetary policies without constraining the economy to a welfare-inferior equilibrium. However, this requires the computation of optimal monetary policy frontiers and an appropriate utility-based quadratic loss function. A possible amendment to the EU accession requirement could be to set a target in terms of inflation and depreciation/appreciation rate of the nominal exchange rate. This would still rule out a number of non-virtuous monetary policies during the accession phase, while allowing countries to choose their preferred combination of targets within a range compatible with the B-S effect. In this context, there would be no reason for the EU to mandate which point of the policy frontier a country should choose.

Finally, the starting point in our analysis is the assumption that EU candidate countries will join the EMU. Accordingly, we investigate the costs related to meeting the accession criteria for a country credibly committed to 
joining the Euro. Some countries might gain an extra benefit from fixing their exchange rate as soon as possible. They might lack the credibility to conduct monetary policy without an external anchor; or they might assess that some of the benefits from joining the currency area (such as increased trade or FDI) could be brought forward by fixing the exchange rate. These benefits could then outweigh the welfare cost highlighted by our analysis for countries that choose to manage the external value of their currency. It is also true, though, that convergence criteria are meant to assure that an economy is sufficiently attuned with the rest of the Euro area to adopt the common currency. The problems raised by the B-S effect may also have consequences for the EU candidate countries after joining the Euro currency area, possibly causing tension in the administration of a common monetary policy.

\section{References}

[1] Arratibel, O., Rodriguez-Palenzuela, D. and Thimann, C., (2002), 'Inflation dynamics and dual inflation in accession countries: a New Keynesian perspective', ECB Working Paper 132.

[2] Backus, D., Kydland, F. and P. Kehoe, (1992), 'International real business cycles', Journal of Political Economy.

[3] Benigno, P., (2001), 'Inflation targeting in open economies', mimeo, NYU.

[4] Buiter, W. and Grafe, C., (2002), 'Anchor, float or abandon ship: exchange rate regimes for accession countries", CEPR Discussion Paper No. 3184 .

[5] Calvo, G., (1983), 'Staggered prices in a utility-maximizing framework', Journal of Monetary Economics 12: 383-398.

[6] Canzoneri, M., Cumby, R. and Diba, B., (1999), "Relative labor productivity and the real exchange rate in the long run: evidence for a panel of OECD countries", Journal of International Economics, 47: 245-266.

[7] Canzoneri, M., Cumby, R., Diba, B. and Eudey G., (2001), "Productivity trends in Europe: Implications for real exchange rates, real interest rates and inflation", Georgetown University, mimeo. 
[8] Cihak, M. and Holub, T., (2001), 'Convergence in relative prices and inflation in central and eastern Europe', IMF WP 01/124.

[9] Cipriani, M., (2001), "The Balassa-Samuelson effect in transition economies', New York University, mimeo.

[10] Clarida, R., Gali, J. and Gertler, M., (1999), 'The science of monetary policy: a new keynesian perspective', Journal of Economic Literature 37: 1661-1707.

[11] - (1998), 'Monetary policy in practice: some international evidence', European Economic Review 42: 1033-1067.

[12] Cook, D. and Devereux, M., (2001), 'The macroeconomics of international financial panics', mimeo, University of British Columbia.

[13] Corker, R., Beaumont, C., Van Elkan, E. and Iakova, D., (2000), 'Exchange rate regimes in selected advanced transition economies - coping with transition, capital inflows, and EU accession', IMF Policy Discussion Paper No. 3.

[14] De Broek, M. and Slok, T., (2001), 'Interpreting real exchange rate movements in transition countries', IMF WP 01/56.

[15] De Gregorio, J., Giovannini, A. and Wolf, H., (1994), 'International evidence on tradables and non-tradable inflation', European Economic Review 38: 1225-1244.

[16] Dennis, R., (2002), 'Solving for Optimal Simple Rules in Rational Expectations Models', mimeo, Federal Reserve Bank of San Francisco.

[17] Devereux, M., (2001), 'Monetary policy, exchange rate flexibility and exchange rate pass-through', mimeo, University of British Columbia.

[18] Devereux, M. (2002), 'Monetary policy strategies for emerging market countries: the case of East European accession countries', mimeo, University of British Columbia.

[19] Devereux, M. and Lane, P., (2001), 'Exchange rates and monetary policy in emerging market economies", mimeo.

[20] ECOFIN Council, (2000), "Ecofin Council conclusions on exchange rate strategies for accession countries", Brussels. 
[21] Egert, B., (2002), 'Estimating the impact of the Balassa-Samuelson effect on inflation and the real exchange rate during the transition', Economic Systems 26: 1-16.

[22] Fischer, C., (2002), 'Real currency appreciation in accession countries: Balassa-Samuelson and Investment demand', BOFIT Discussion Papers 8 .

[23] Gali, J. and Monacelli, T., (2002), 'Optimal monetary policy and exchange rate volatility in a small open economy', mimeo.

[24] Kollman, R., (2001), 'Monetary rules in the open economy: effects of welfare and business cycle', mimeo, University of Bonn.

[25] Kovacs, A., (1998), 'Components of the real exchange rate in Hungary', National Bank of Hungary WP 1998/3.

[26] Laxton, D. and Pesenti, P., (2002), 'Monetary Rules for Small, Open, Emerging Economies', mimeo, IMF.

[27] Mahadeva, L. and Smidkova, K., (2000), 'Modeling the transmission mechanism of monetary policy in the Czech Republic', in Mahadeva, L. and Stern, G., eds., Monetary Policy Frameworks in a Global Context, London: Routledge.

[28] Masson, P., (1999), 'Monetary and exchange rate policy of transition economies of Central and Eastern Europe after the launch of EMU', IMF Policy Discussion Paper No. 5.

[29] Mendoza, E., (1995), 'The terms of trade, the real exchange rate, and economic fluctuations', International Economic Review 36: 101-137.

[30] Mendoza, E. and Uribe, M., (1999), 'Devaluation risk and the syndrome of exchange-rate based stabilizations', NBER WP 7014.

[31] Mihaljek, D., (2002), 'The Balassa-Samuelson Effect in central Europe: a disaggregated analysis', Bank for International Settlements, mimeo.

[32] Nenovsky, N. and Dimitrova, K., (2002), 'Dual inflation under the currency board: the challenges of Bulgarian accession', The William Davidson Institute, Working Paper 487.

[33] Obstfeld, M. and Rogoff, K., (1995), 'The mirage of fixed exchange rate', Journal of Economic Perspective 9: 73-96. 
[34] Obstfeld, M. and Rogoff, K., (1999), 'New directions for stochastic open economy models', NBER Working Paper No. 7313,

[35] Pelkmans, J., Gros, D. and Ferrer, J., (2000), 'Long run economic aspects of the European Union Eastern enlargement', Netherlands Scientific Council for Government Policy, Working Document W109.

[36] Ravenna, F., forthcoming, 'Inflation Targeting in Canada: a Structural Analysis', Santa Cruz Center for International Economics Working Paper.

[37] Rogers, J., (2001), 'Price level convergence, relative prices, and inflation in Europe', Board of Governors of the Federal Reserve System, IFDP No. 699 .

[38] Rogers, J., (2002), 'Monetary Union, price level convergence, and inflation: how close is Europe to the United States?', Board of Governors of the Federal Reserve System, IFDP No. 740.

[39] Schmitt-Grohe, S. and Uribe, M., (2001), 'Stabilization policy and the costs of dollarization', Journal of Money, Credit, and Banking 33: 482509 .

[40] Stockman, A. and Tesar, L., (1995), "Tastes and technology in a two country model of the business cycle', American Economic Review 85: 168-185.

[41] Svensson, L., (2000), 'Open-economy inflation targeting', Journal of International Economics 50: 155-183.

[42] Szapary, G, (2000), 'Maastricht and the choice of exchange rate regime in transition countries during the run-up to EMU', National Bank of Hungary Working Paper No.7.

[43] Taylor, J., (1983), 'Discretion versus policy rules in practice', CarnegieRochester Conference Series on Public Policy.

[44] Tille, C., (2002), 'How valuable is exchange rate flexibility? Optimal monetary policy under sectoral shocks', Federal Reserve Bank of New York Staff Report 147.

[45] Uribe, M., (1996), 'Exchange-rate based inflation stabilization: the initial real effects of credible plans', Journal of Monetary Economics 39: 197-221. 
[46] Von Hagen, J. and Zhou, J., (2001), 'The choice of exchange rate regimes: an empirical analysis for transition economies', mimeo, University of Bonn.

\section{Appendix: the Log-linearized Model}

In this Appendix we present the equations of the model in log-linear form. Note that we use lower case letters to indicate log-linear variables.

\subsection{Composites and Inflation Rates}

$$
\begin{gathered}
c_{t}=\left(\gamma_{c n}\right)^{\frac{1}{\rho_{c n}}}\left(\frac{C_{N}}{C}\right)^{\frac{\rho_{c n}-1}{\rho_{c n}}} c_{N, t}+\left(1-\gamma_{c n}\right)^{\frac{1}{\rho_{c n}}}\left(\frac{C_{T}}{C}\right)^{\frac{\rho_{c n}-1}{\rho_{c n}}} c_{T, t} \\
c_{T, t}=\left(\gamma_{c h}\right)^{\frac{1}{\rho_{c h}}}\left(\frac{C_{H}}{C_{T}}\right)^{\frac{\rho_{c h}-1}{\rho_{c h}}} c_{H, t}+\left(1-\gamma_{c h}\right)^{\frac{1}{\rho_{c h}}}\left(\frac{C_{F}}{C_{T}}\right)^{\frac{\rho_{c h}-1}{\rho_{c h}}} c_{F, t} \\
i_{t}^{J}=\left(\gamma_{i n}\right)^{\frac{1}{\rho_{i n}}}\left(\frac{I_{N}^{J}}{I^{J}}\right)^{\frac{\rho_{i n}-1}{\rho_{i n}}} i_{N, t}^{J}+\left(1-\gamma_{i n}\right)^{\frac{1}{\rho_{i n}}}\left(\frac{I_{T}^{J}}{I^{J}}\right)^{\frac{\rho_{i n}-1}{\rho_{i n}}} i_{T, t}^{J}, J=N, H \\
i_{T, t}^{J}=\left(\gamma_{i h}\right)^{\frac{1}{\rho_{i h}}}\left(\frac{I_{H}^{J}}{I_{T}^{J}}\right)^{\frac{\rho_{i h}-1}{\rho_{i h}}} i_{H, t}^{J}+\left(1-\gamma_{i h}\right)^{\frac{1}{\rho_{i h}}}\left(\frac{I_{F}^{J}}{I_{T}^{J}}\right)^{\frac{\rho_{i h}-1}{\rho_{i n}}} i_{F, t}^{J}, J=N, H \\
\pi_{t}^{c}=\left(\gamma_{c n}\right)\left(\frac{P_{N}}{P^{c}}\right)^{1-\rho_{c n}} \pi_{N, t}+\left(1-\gamma_{c n}\right)\left(\frac{P_{T}^{c}}{P^{c}}\right)^{1-\rho_{c n}} \pi_{T, t}^{c} \\
\pi_{T, t}^{c}=\left(\gamma_{c h}\right)\left(\frac{P_{H}}{P_{T}^{c}}\right)^{1-\rho_{c h}} \pi_{H, t}+\left(1-\gamma_{c h}\right)\left(\frac{P_{F}}{P_{T}^{c}}\right)^{1-\rho_{c h}} \pi_{F, t} \\
\pi_{t}^{i}=\left(\gamma_{i n}\right)\left(\frac{P_{N}}{P^{i}}\right)^{1-\rho_{i n}} \pi_{N, t}+\left(1-\gamma_{i n}\right)\left(\frac{P_{T}^{i}}{P^{i}}\right)^{1-\rho_{i n}} \pi_{T, t}^{i} \\
\pi_{T, t}^{i}=\left(\gamma_{i h}\right)\left(\frac{P_{H}}{P_{T}^{i}}\right)^{1-\rho_{i h}} \pi_{H, t}+\left(1-\gamma_{i h}\right)\left(\frac{P_{F}}{P_{T}^{i}}\right)^{1-\rho_{i h}} \pi_{F, t}
\end{gathered}
$$

Equations (56) and (57) are total and tradable consumption indices. Equations (58) and (59) are total and tradable investment indices in sector $J$. Equations (60) and (61) are CPI and consumption tradable inflation rates. Finally, equations (62) and (63) are investment price inflation and investment tradable inflation rates. 


\subsection{Household's FOCs}

$$
\begin{gathered}
\lambda_{t}^{C}=\lambda_{t+1}^{C}+r_{t} \\
i_{t}=i_{t}^{*}+\Delta e_{t+1} \\
c_{N, t}=\rho_{c n} * q_{t}^{c}+c_{T, t} \\
c_{H, t}=\rho_{c h} * s_{F, t}+c_{F, t} \\
i_{N, t}^{J}=\rho_{i n} * q_{t}^{i}+i_{T, t}^{J}, J=N, H \\
i_{H, t}^{J}=\rho_{i h} * s_{F, t}+i_{F, t}^{J}, J=N, H \\
q_{t}^{J}=\eta\left(i_{t}^{J}-k_{t-1}^{J}\right), J=N, H \\
\lambda_{t}^{C}+p_{t}^{i c}+q_{t}^{J}=\lambda_{t+1}^{C}+[1-\beta(1-\delta)] z_{J, t+1}+\beta(1-\delta)\left(p_{t+1}^{i c}+q_{t+1}^{J}\right)+\beta \eta \delta\left(i_{t+1}^{J}-k_{t}^{J}\right) \\
k_{t}^{J}=\delta i_{t}^{J}+(1-\delta) k_{t-1}^{J}, J=N, H
\end{gathered}
$$

Equation (64) is the Euler equation, where $\lambda_{t}^{C}$, the marginal utility of total consumption, is defined as

$$
\lambda_{t}^{C}=-c_{t}
$$

and the consumption-based real interest rate, $r_{t}$, is obtained from the Fisher equation:

$$
r_{t}=i_{i}-E_{t}\left\{\pi_{t+1}^{c}\right\}
$$

Equation (65) is the Uncovered Interest Parity Condition. Equations (66) and (67) are the intra-temporal allocations of total consumption and tradable consumption, respectively, where the consumption-based real exchange rate, $q_{t}^{c}$, is defined as

$$
q_{t}^{c}=q_{t-1}^{c}+\pi_{T, t}^{c}-\pi_{N, t}
$$

and the term of trade $s_{F, t}$ is given by

$$
s_{F, t}=s_{F, t-1}+\pi_{F, t}-\pi_{H, t}
$$

Similarly, equations (68) and (69) are the intra-temporal allocations of total investment and tradable investment in sector $J$, respectively, where the investment-based real exchange rate $q_{t}^{i}$ is given by

$$
q_{t}^{i}=q_{t-1}^{i}+\pi_{T, t}^{i}-\pi_{N, t}
$$


Equation (70) is Tobin's Q in sector $J$, where the elasticity $\eta$ is defined as

$$
\eta=-\Phi_{s s}^{\prime \prime} \frac{\frac{I^{J}}{K^{J}}}{\Phi_{s s}^{\prime}}
$$

Equation (71) is the inter-temporal investment choice for sector specific capital $K_{t}^{J}$, where the rental rates of capital in sector $N$ and $H, z_{N, t}$ and $z_{H, t}$ respectively, are given by

$$
\begin{gathered}
z_{N, t+1}=p_{t}^{n c}+m c_{t+1}^{N}+y_{N, t+1}-k_{t}^{N} \\
z_{H, t}=p_{t}^{h c}+v_{H, t}-k_{t-1}^{H}+\frac{1}{\rho_{v}}\left(y_{H, t}-v_{H, t}\right)
\end{gathered}
$$

and

$$
\begin{gathered}
p_{t}^{i c}=p_{t-1}^{i c}+\pi_{t}^{i}-\pi_{t}^{c} \\
p_{t}^{n c}=p_{t-1}^{n c}+\pi_{N, t}-\pi_{t}^{c} \\
p_{t}^{h c}=p_{t-1}^{h c}+\pi_{H, t}-\pi_{t}^{c}
\end{gathered}
$$

Finally, equation (72) is the law of motion of capital in sector $J$.

\subsection{Labor Market Equilibrium}

$$
\begin{gathered}
\eta_{H} h_{t}=m c_{t}^{N}+y_{N, t}-h_{t}^{N}+p_{t}^{n c}+\lambda_{t}^{C} \\
\eta_{H} h_{t}=v_{H, t}+\frac{1}{\rho_{v}}\left(y_{H, t}-v_{H, t}\right)-h_{t}^{H}+p_{t}^{h c}+\lambda_{t}^{C} \\
h_{t}=\frac{H_{N}}{H} h_{t}^{N}+\frac{H_{H}}{H} h_{t}^{H}
\end{gathered}
$$

Equations (83) and (84) define the labor market equilibrium in the $N$ and $H$ sectors. Equation (85) equalizes total labor supply and demand.

\subsection{Production functions}

$$
\begin{gathered}
y_{N, t}=a_{t}^{N}+\alpha_{n} k_{t-1}^{N}+\left(1-\alpha_{n}\right) h_{t}^{N} \\
y_{H, t}=\left(\gamma_{v}\right)^{\frac{1}{\rho_{v}}}\left(\frac{V_{H}}{Y_{H}}\right)^{\frac{\rho_{v}-1}{\rho_{v}}} v_{H, t}+\left(1-\gamma_{v}\right)^{\frac{1}{\rho_{v}}}\left(\frac{X_{M}}{Y_{H}}\right)^{\frac{\rho_{v}-1}{\rho_{v}}} x_{M, t} \\
v_{H, t}=a_{t}^{H}+\alpha_{h} k_{t-1}^{H}+\left(1-\alpha_{h}\right) h_{t}^{H}
\end{gathered}
$$

Equation (86) is the production function in the $N$ sector. Equation (87) is the production function in the domestic tradable sector $H$. Equation (88) is the value added function in the domestic tradable sector $H$. 


\subsection{Imported intermediate Input Demand}

$$
s_{M, t}=\frac{1}{\rho_{v}}\left(y_{H, t}-x_{M, t}\right)
$$

Equation (89) is the demand for the imported intermediate good $X_{M}$.

\subsection{Pricing and Law of One Price}

$$
\begin{gathered}
\pi_{N, t}=\lambda m c_{t}^{N}+\beta E_{t}\left(\pi_{N, t+1}\right) \\
\pi_{H, t}=e_{t}-e_{t-1}+\pi_{H, t}^{*} \\
\pi_{F, t}=e_{t}-e_{t-1}+\pi_{F, t}^{*} \\
\pi_{M, t}=e_{t}-e_{t-1}+\pi_{M, t}^{*}
\end{gathered}
$$

Equation (90) is the forward-looking Phillips curve in the $N$ sector. Equations (91), (92), and (93) are the Law of One Price for goods $H, F$, and $M$.

\subsection{Resource Constraints}

$$
\begin{gathered}
y_{N, t}=\frac{C_{N}}{Y_{N}} c_{N, t}+\frac{I_{N}^{N}}{Y_{N}} i_{N, t}^{N}+\frac{I_{N}^{H}}{Y_{N}} i_{N, t}^{H}+\frac{G_{N}}{Y_{N}} g_{N, t} \\
y_{H, t}=\frac{C_{H}}{Y_{H}} c_{H, t}+\frac{I_{H}^{N}}{Y_{H}} i_{H, t}^{N}+\frac{I_{H}^{H}}{Y_{H}} i_{H, t}^{H}+\frac{G_{H}}{Y_{H}} g_{H, t}+\frac{C_{H}^{*}}{Y_{H}} c_{H, t}^{*} \\
\widetilde{N X}{ }_{H, t}=\frac{C_{H}^{*}}{Y_{H}} c_{H, t}^{*}-S_{F} \frac{C_{F}}{Y_{H}} c_{F, t}-S_{F} \frac{I_{F}^{N}}{Y_{H}} i_{F, t}^{N}-S_{F} \frac{I_{F}^{H}}{Y_{H}} i_{F, t}^{H}-S_{M} \frac{X_{M}}{Y_{H}} x_{M, t} \\
-S_{F}\left(\frac{C_{F}+I_{F}^{N}+I_{F}^{H}}{Y_{H}}\right) s_{F, t}-S_{M} \frac{X_{M}}{Y_{H}} x_{M, t} \\
\widetilde{B}_{H, t}=\frac{\left(1+i^{*}\right)}{\left(1+\pi_{H}\right)} \widetilde{B}_{H, t-1}+\widetilde{N X_{H, t}}
\end{gathered}
$$

Equations (94) and (95) are the resource constraints in the $N$ and $H$ sector. Equation (96) is the trade balance, in units of good $H$, assuming a balanced-trade steady state, where $\widetilde{N X}_{H, t}$ is defined as

$$
\widetilde{N X}_{H, t}=\frac{N X_{H, t}}{Y_{H}}
$$


and $S_{F}$ and $S_{M}$ are the steady state values of the terms of trade. Equation (97) is the current account in $H$ units, where $B_{H, t}$ is defined as

$$
B_{H, t}=\frac{e_{t} B_{t}^{*}}{P_{H, t}}
$$

and, in a balanced trade steady state, $\widetilde{B}_{H, t}=\frac{B_{H, t}}{Y_{H}}$.

The log-linearized risk premium equation is then given by:

$$
i_{t}^{*}=\tilde{i}_{t}^{*}-\tilde{\eta} Y_{H} \widetilde{B}_{H, t}
$$

where $\tilde{\eta}$ is the elasticity of the foreign interest rate with respect to the debt, and $\tilde{i}_{t}^{*}$ is the world interest rate.

\subsection{Shocks}

Exogenous shocks are assumed to follow an $\mathrm{AR}(1)$ process. 
Table 1: Exogenous Shocks Parameters

\section{VARIABLE}

Tradable Good Productivity Non-tradable Good Productivity Government Non-tradable Good Demand

Foreign Tradable Good Inflation

Foreign Import Price (consumption good)

Foreign Import Price (intermediate good)

Foreign Interest Rate

Domestic Interest Rate Innovations
STD DEV \%

AUTOCORR

1.81

0.96

0.85

$4.64 *$

1.23

0.98

0.98

$0.59 *$

0.38

Note: * indicates that a parameter is estimated from the data. All other parameters for the exogenous shocks stochastic processes are calibrated. See Table 2 for details on data used. The policy rule is calibrated to $\mathrm{i}(\mathrm{t})=0.9^{*}[\mathrm{i}(\mathrm{t}-1)]+0.1^{*}\left[0.5^{*} \pi(\mathrm{t})+0.5^{*} \mathrm{e}(\mathrm{t})\right]$. 
Table 2: Model Simulation Moments

\begin{tabular}{|c|c|c|c|c|}
\hline Statistics & Simulation & & Czech Republic & G-7 (1973-1996) \\
\hline $\begin{array}{l}\text { Standard Deviation \% } \\
\text { Output }\end{array}$ & 1.505 & $(0.332)$ & 2.469 & 1.85 \\
\hline $\begin{array}{l}\text { Consumption } \\
\text { Investment } \\
\text { Investment-Non-Tradable Sector }\end{array}$ & $\begin{array}{l}3.818 \\
9.269\end{array}$ & $\begin{array}{l}(0.63) \\
(1.571)\end{array}$ & $\begin{array}{l}2.694 \\
9.469\end{array}$ & 1.59 \\
\hline Investment-Tradable Sector & 4.693 & $(0.811)$ & & \\
\hline Net Exports & 4.925 & (0.8) & 2.773 & \\
\hline Nominal Interest Rate & 0.579 & $(0.15)$ & 0.783 & 0.45 \\
\hline Nominal Exchange Rate & 1.693 & $(0.30)$ & 3.338 & 4.8 \\
\hline Real Exchange Rate & 2.167 & $(0.461)$ & 2.853 & 4.75 \\
\hline CPI Inflation Rate & 1.624 & (0.319) & 1.057 & \\
\hline $\begin{array}{l}\text { Contemporaneous correlation } \\
\text { with domestic output }\end{array}$ & & & & \\
\hline $\begin{array}{l}\text { Consumption } \\
\text { Investment }\end{array}$ & 0.62 & $(0.11)$ & $\begin{array}{c}0.66 \\
0.8\end{array}$ & 0.75 \\
\hline Investment-Non-Tradable Sector & 0.66 & $(0.11)$ & & \\
\hline Investment-Tradable Sector & 0.6 & $(0.13)$ & & \\
\hline Net Exports & -0.31 & $(0.17)$ & -0.16 & \\
\hline Nominal Interest Rate & 0.35 & $(0.37)$ & 0.28 & 0.03 \\
\hline Nominal Exchange Rate & 0.22 & $(0.26)$ & 0.32 & -0.16 \\
\hline Real Exchange Rate & -0.14 & $(0.27)$ & -0.04 & -0.06 \\
\hline CPI Inflation Rate & 0.56 & $(0.14)$ & 0.44 & \\
\hline
\end{tabular}

Note: Standard deviation of simulation estimates is in brackets. All series are Hodrick-Prescott filtered except for inflation rate, nominal interest rate and net exports. The net export variable is scaled by HP-filtered output. Rates of change are quarterly. Data sample for Czech Republic is 1993:4 - 2002:1. G-7 columns shows arithmetic averages of statistics across US, Japan, Germany, France, UK, Italy and Canada, as reported in Kollmann (2001). See appendix for full details on data. 


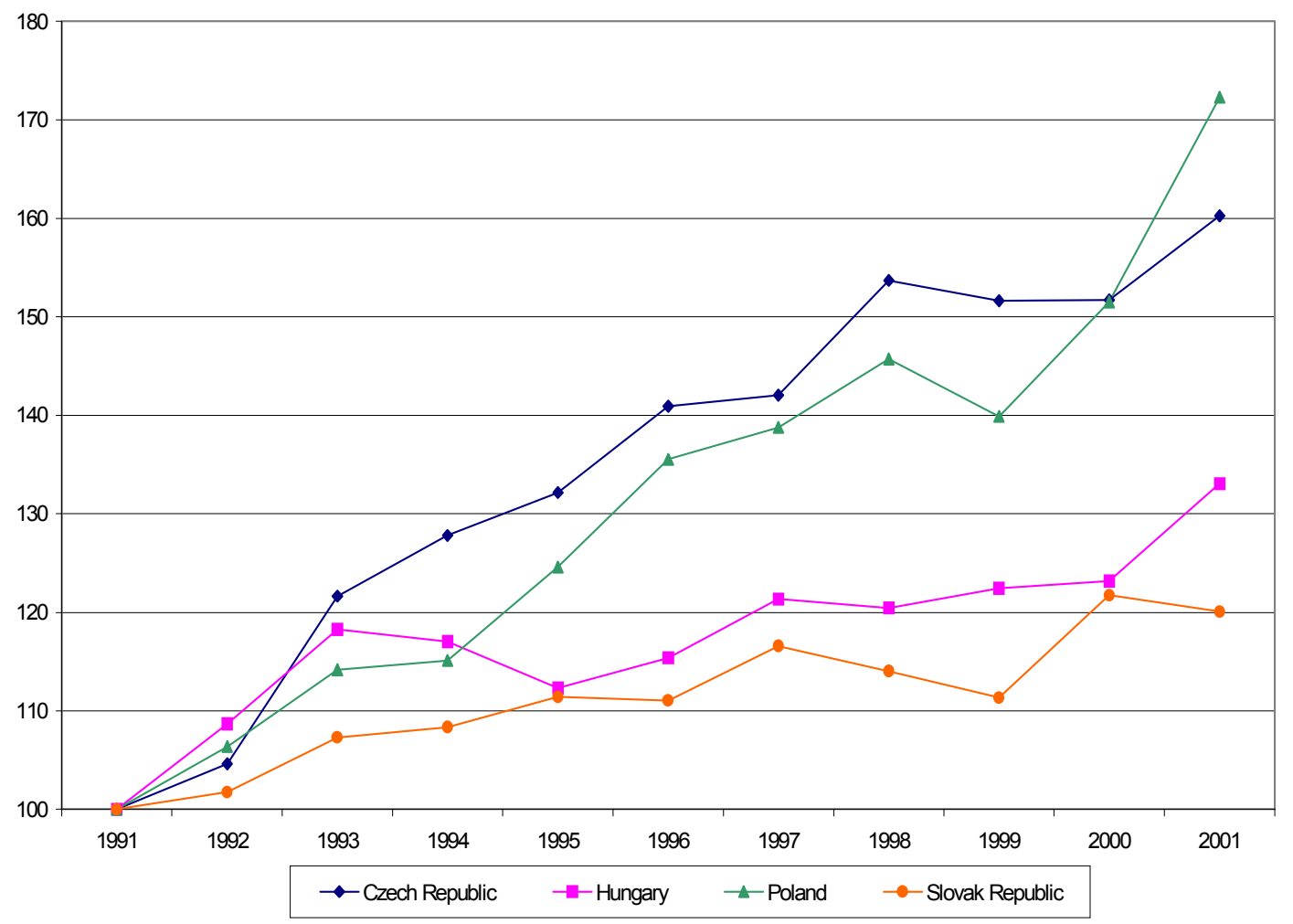

Figure 1: Real Effective Exchange Rate (IMF-IFS, 1991=100) 

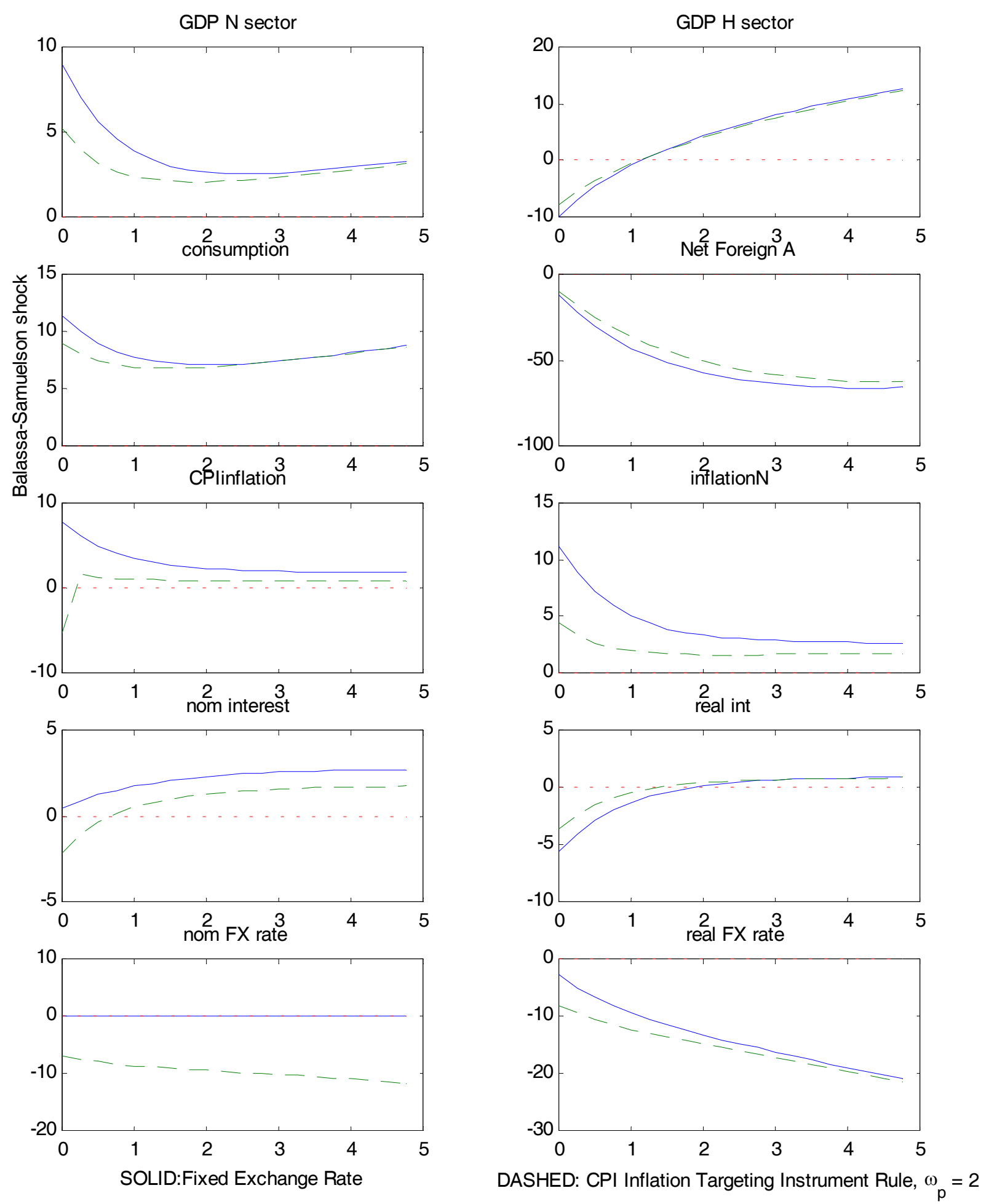

Figure 2: Impulse Response Function to a persistent tradable-sector productivity growth shock. Productivity grows by $30 \%$ over a 10 -year period. Taylor rule coefficient: $\omega_{\pi}=2$. 

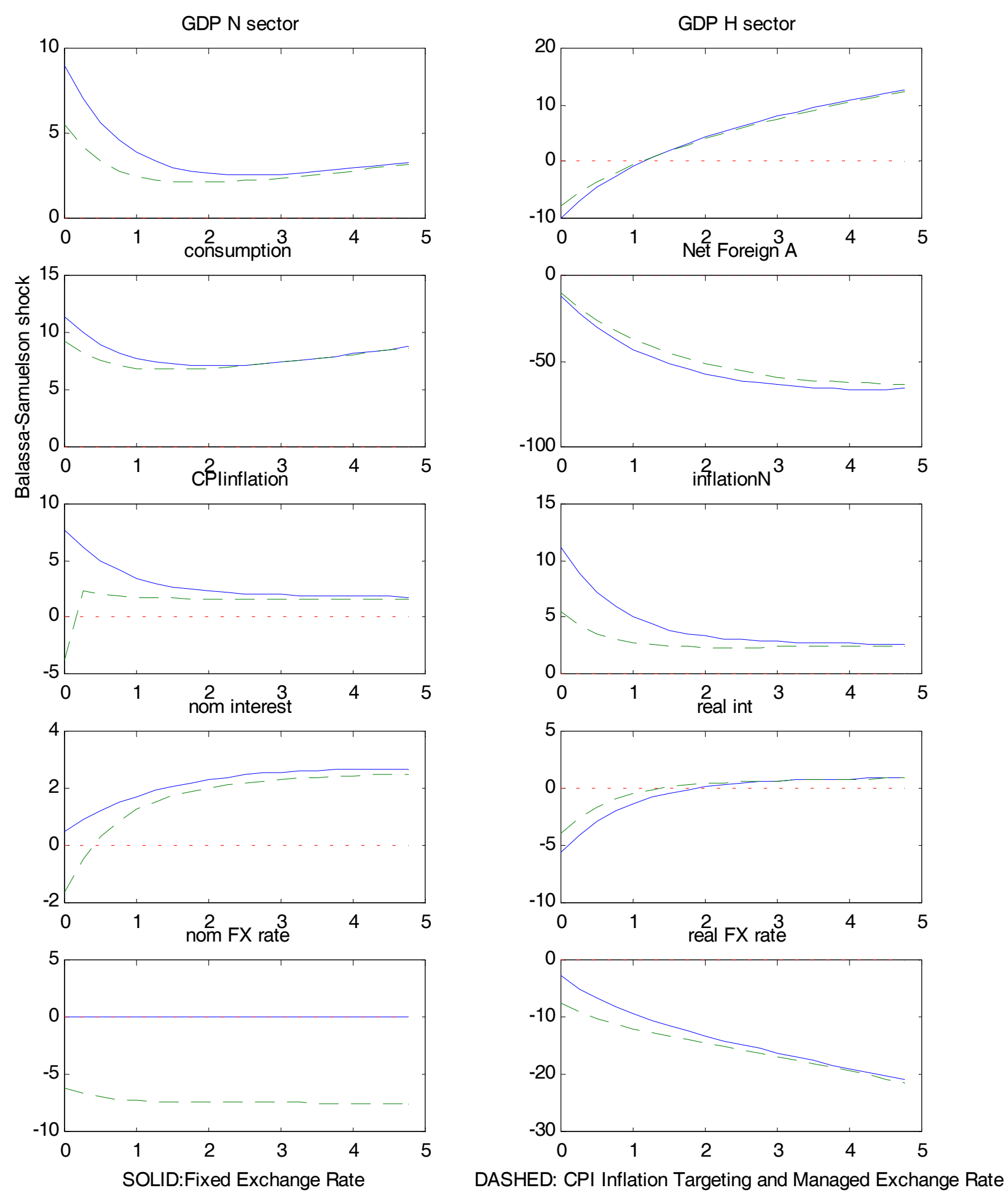

Figure 3: Impulse Response Function to a persistent tradable-sector productivity growth shock. Productivity grows by $30 \%$ over a 10 -year period. Taylor rule coefficients: $\omega_{\pi}=2, \omega_{e}=0.025$. 

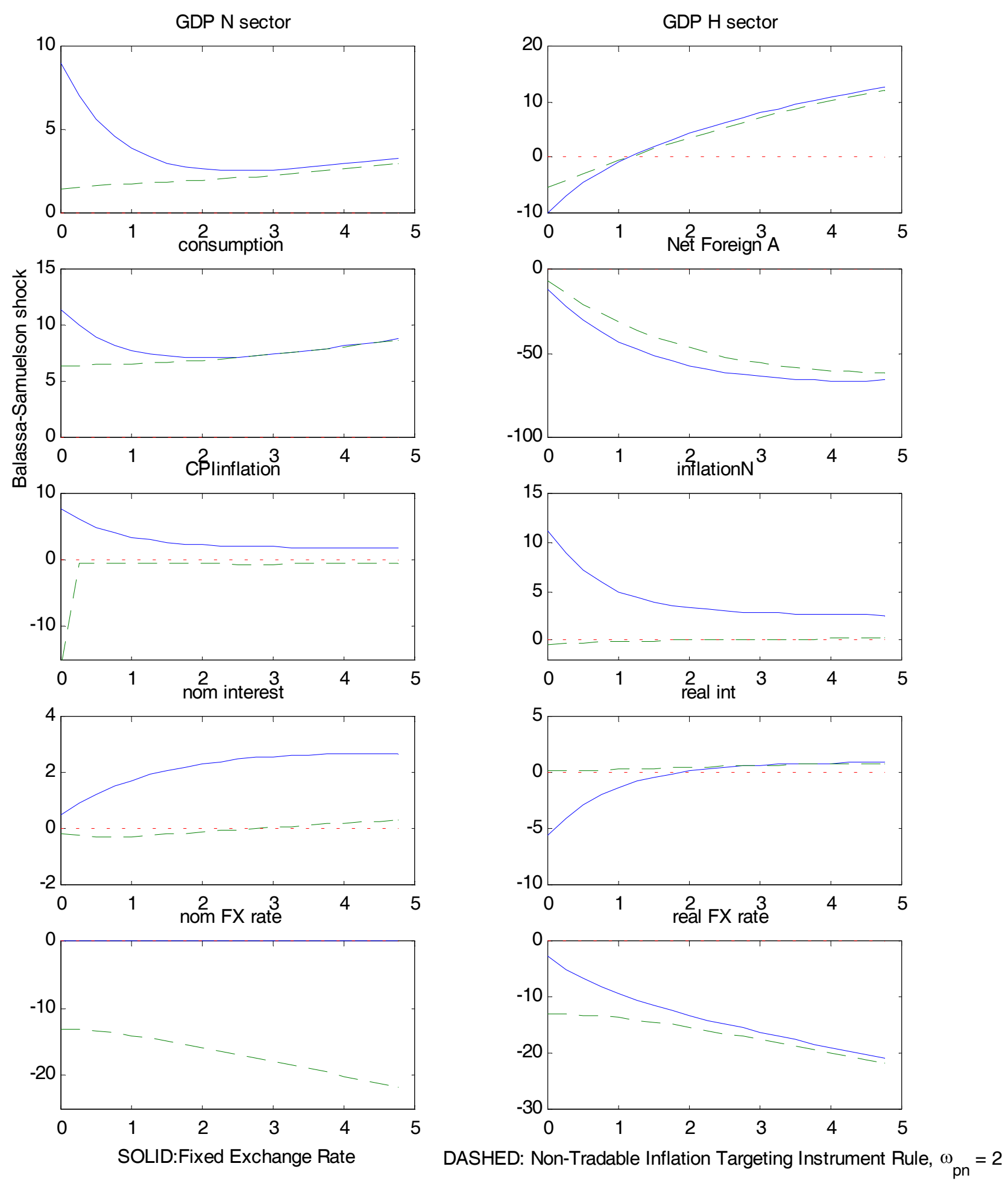

Figure 4: Impulse Response Function to a persistent tradable-sector productivity growth shock. Productivity grows by $30 \%$ over a 10 -year period. Taylor rule coefficient: $\omega_{\pi_{N}}=2$. 

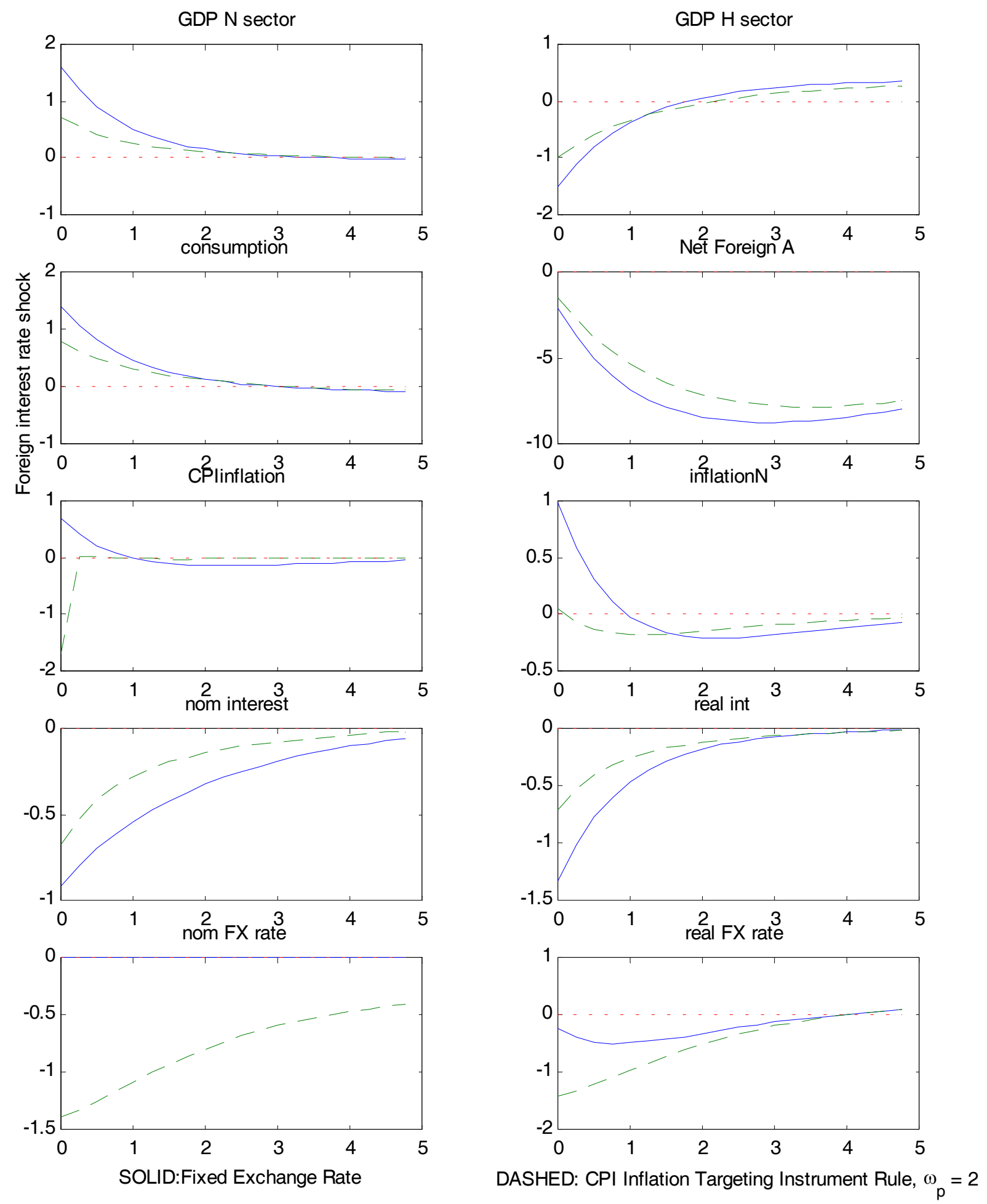

Figure 5: Impulse Response Function to 1\% drop in the annualized foreign risk premium. 


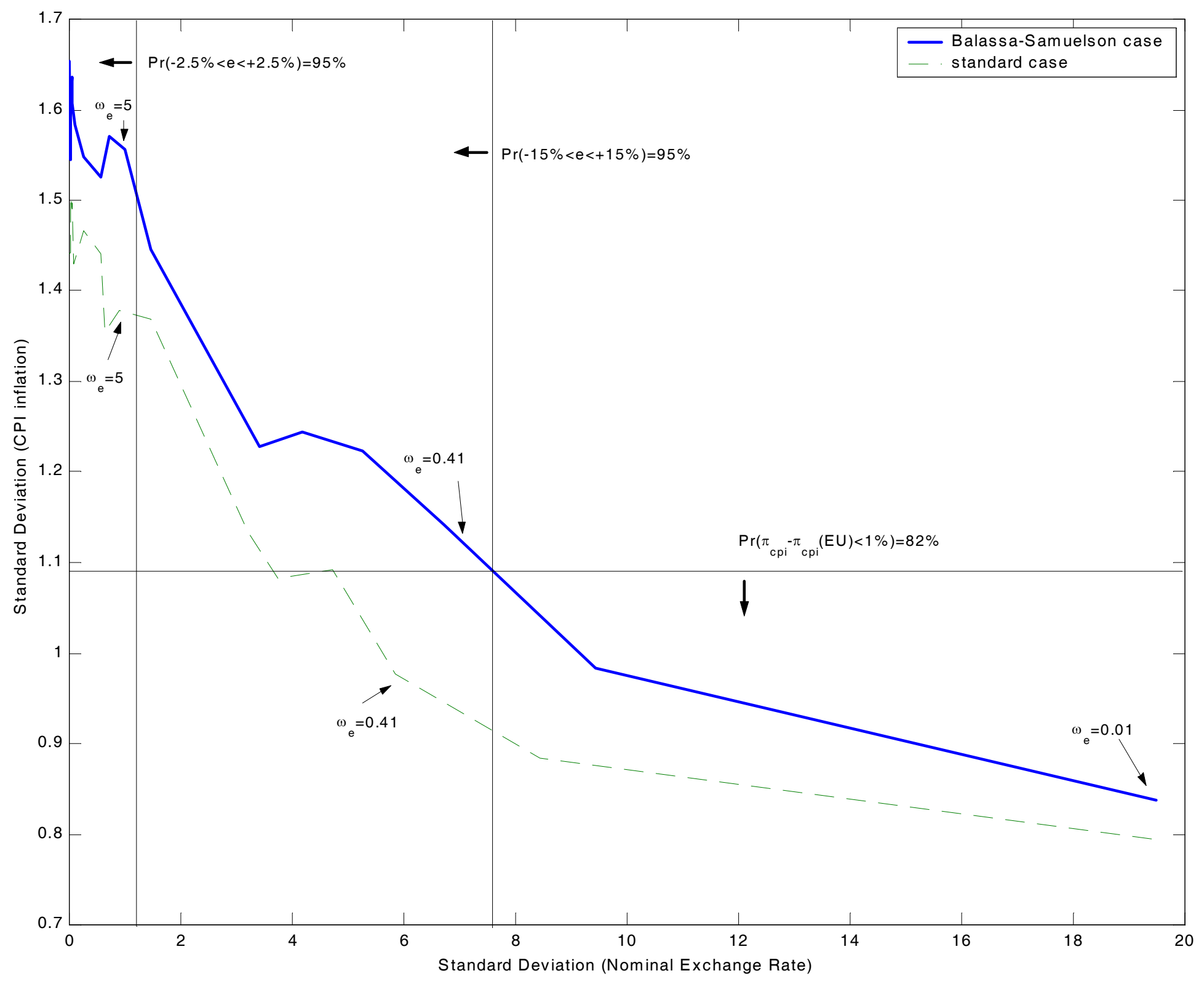

Figure 6: Inflation/exchange rate Volatility Trade-off for policy rule $i_{t}=$ $\chi i_{t-1}+(1-\chi)\left[\omega_{\pi} \pi_{t}+\omega_{e} e_{t}\right]$ for $\omega_{e} \in[700,0.1]$. Solid: tradable-sector productivity grows on average by $2.65 \%$ per year (30\% over a 10 -year period). Dashed: tradable-sector productivity follows AR(1) process. All exogenous shocks parameters are in Table 1. Probability boundaries (solid vertical and horizontal lines) are computed for the Standard case. Points to the left or below the $\alpha$-probability boundary are combinations $\left(\sigma_{\pi}, \sigma_{e}\right)$ such that the probability of the realization $\xi$ in any quarter, $\operatorname{Pr}(\xi)$, is larger than $\alpha$. 


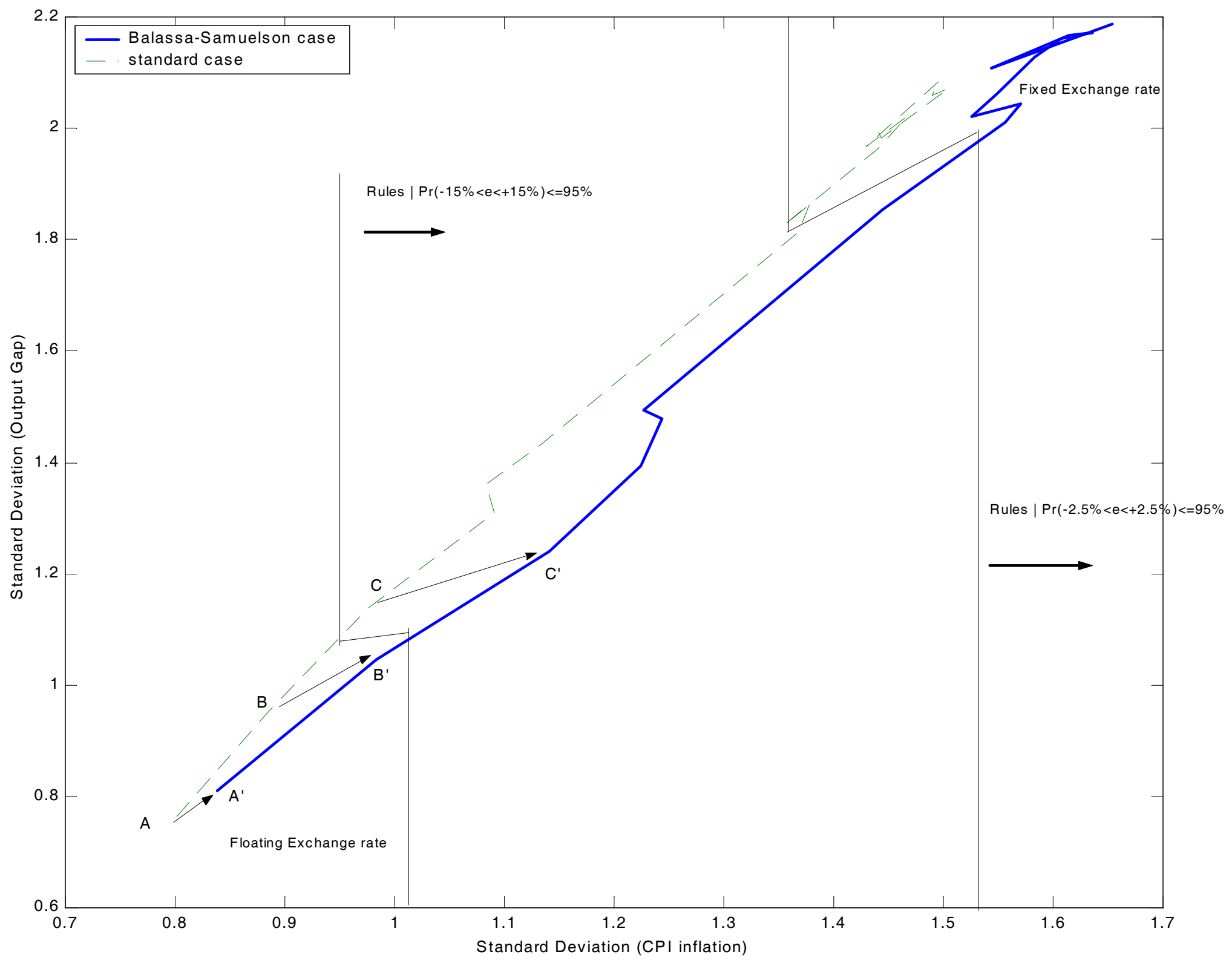

Figure 7: Inflation/output gap Volatility Trade-off for policy rule $i_{t}=$ $\chi i_{t-1}+(1-\chi)\left[\omega_{\pi} \pi_{t}+\omega_{e} e_{t}\right]$ for $\omega_{e} \in[700,0.1]$. Solid: tradable-sector productivity grows on average by $2.65 \%$ per year (30\% over a 10 -year period). Dashed: tradable-sector productivity follows $\mathrm{AR}(1)$ process. All exogenous shocks parameters are in Table 1 . Points $\left(\sigma_{y g a p}, \sigma_{\pi}\right)$ to the right of the solid vertical lines occur for policy rules such that the nominal exchange rate fluctuation in every quarter is within a $30 \%(5 \%)$ band with $95 \%$ probability. These rules correspond to points to the left of the probability boundaries in $\square$ Fig. $\square$ 6. $\square$ Point $\square A, A^{\prime} ; \square B, B^{\prime} ; C, C^{\prime} \square$ are $\square$ plot $\_$for $\square$ values $\square$ of $\omega e_{e}=[0.01$, $0.21,0.41]$. 


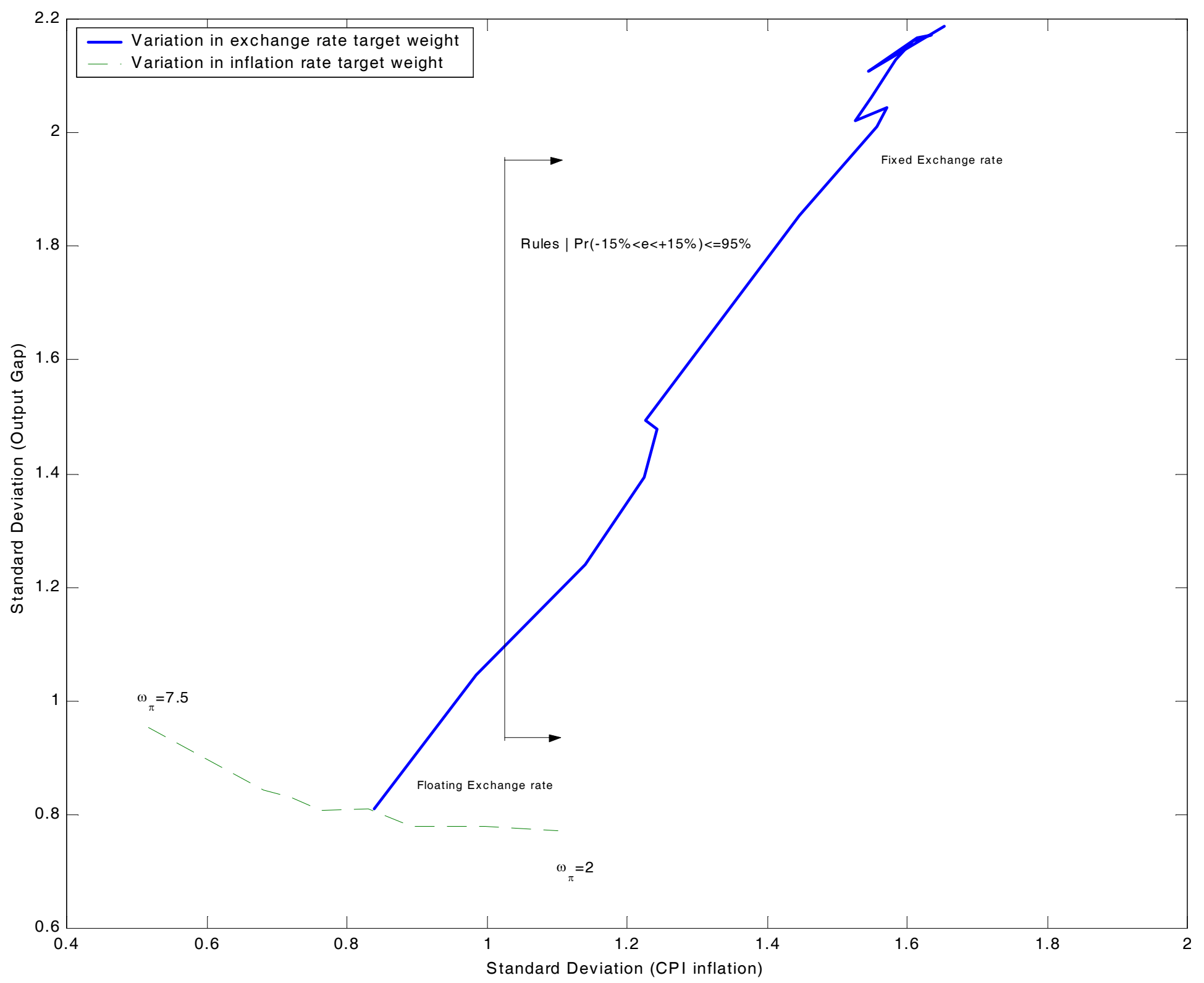

Figure 8: Inflation/output gap Volatility Trade-off. Solid line: policy rule $i_{t}=\chi i_{t-1}+(1-\chi)\left[\omega_{\pi} \pi_{t}+\omega_{e} e_{t}\right], \omega_{e} \in[700,0.1]$. Dashed line: policy rule $i_{t}=\chi i_{t-1}+(1-\chi) \omega_{\pi} \pi_{t}$ for $\omega_{\pi} \in[7.5,2]$. Both lines are drawn for the case of tradable-sector productivity growing on average by $2.65 \%$ per year $(30 \%$ over a 10-year period). Other exogenous shock parameters are as in Table 1. Points $\left(\sigma_{\text {ygap }}, \sigma_{\pi}\right)$ to the right of the vertical line occur for policy rules such that the nominal exchange rate fluctuation in every quarter is within a $30 \%$ band with $95 \%$ probability. These rules correspond to points to the left of the probability boundaries in Fig. 6 . 